\title{
Geochemical Mapping of Iron Quadrangle region by active stream sediments, State of Minas Gerais, Brazil
}

\author{
João Henrique Larizzatti ${ }^{1^{*}}$ \\ Eduardo Duarte Marques ${ }^{2}$ \\ Francisco Valdir Silveira ${ }^{3}$ \\ ${ }^{1}$ CPRM - Geological Survey of Brazil \\ Rio de Janeiro Office* \\ ${ }^{2}$ CPRM - Geological Survey of Brazil \\ Belo Horizonte Regional Office \\ ${ }^{3}$ CPRM - Geological Survey of Brazil \\ Natal Regional Office \\ Corresponding autho \\ Avenida Pasteur, 404 \\ Urca, Rio de Janeiro, RJ, Brazil \\ CEP 22.290-240 \\ Phones: +552125420586 \\ $+5521973167820$ \\ joao.larizzatti@cprm.gov.br
}

\section{RESUMO}

O mapeamento geoquímico do Quadrilátero Ferrífero foi realizado pela CPRM - Serviço Geológico do Brasil com dados geoquímicos de uma área de $45.000 \mathrm{~km}^{2}$ entre os meridianos $42^{\circ} 30^{\prime} \mathrm{W}$ e $45^{\circ} \mathrm{W}$ e paralelos $19^{\circ} 30^{\prime} \mathrm{S}$ e $21^{\circ} \mathrm{S}$. Sedimento ativo de corrente na fração $<80 \#$ (ou 0.175 $\mathrm{mm})$, foi pulverizado a $<150 \#(\sim 0,100 \mathrm{~mm})$, digerido com água régia quente e analisado para 53 elementos (ICPMS). Foram elaborados mapas uni- e multi- elementares. Sedimento de corrente é um meio efetivo no mapeamento geoquímico regional. Estruturas geoquímicas, unidades litológicas e processos de mineralização foram reconhecidos com a densidade de amostragem de 1 amostra por $12 \mathrm{~km}^{2}$. A densidade de amostragem é um fator chave na qualidade dos mapas geoquímicos produzidos. Deve-se tomar cuidado na interpretação dos resultados devido à sua natureza; estes dados não identificam anomalias geoquímicas específicas ou depósitos minerais individuais. A interpretação dos sedimentos de correntes não é direta e os processos secundários envolvidos na evolução deste material devem ser considerados. Estes dados podem ser usados na exploração mineral para se delinear alvos favoráveis para estudos mais detalhados. Depósitos minerais muitas vezes ocorrem em provinciais geoquímicas caracterizadas por elevadas concentrações de elementos de interesse econômico e farejadores. Depósitos minerais tendem a se localizar ao longo de unidades estratigráficas específicas e/ou trends estruturais por grandes áreas. Estes dados geoquímicos podem ser utilizados em estudos ambientais, apoiar tomadores de decisão na definição de políticas públicas e no manuseio sustentável do solo.

Palavras-Chave: mapeamento geoquímico, sedimento de corrente, Quadrilátero Ferrífero, exploração mineral, mapeamento geológico

\section{ABSTRACT}

The geochemical survey of Iron Quadrangle was performed by the Geological Survey of Brazil - CPRM involving geochemical data from the area between $42^{\circ} 30^{\prime} \mathrm{W}$ and $45^{\circ} \mathrm{W}$ and $19^{\circ} 30^{\prime} \mathrm{S}$ and $21^{\circ} \mathrm{S}$, totalling $45.000 \mathrm{~km}^{2}$. Active stream sediment was analyzed. Fine fractions $(<80 \#$ or $0.175 \mathrm{~mm})$ were pulverized to $-150 \#$ fraction $(\sim 0.100 \mathrm{~mm})$, digested by hot acqua regia and analyzed for 53 elements by ICPMS. Maps of raw and manipulated data (element concentrations and multi-elemental scores) were made. Stream sediment $(<80 \#$ fraction $)$ is an effective sampling medium for regional geochemical surveys. Geochemical structures, lithological units and mineralization processes were recognized with the sample density of 1 sample per $12 \mathrm{~km}^{2}$. Sample density has a key role in the quality of the geochemical maps produced. Caution must be taken when interpreting the results because of its nature; these data do not necessarily pinpoint specific geochemical anomalies or single ore deposits. The interpretation of stream sediment samples is not straightforward and must take into account secondary processes involved in the evolution of sampling media. These data may be used in mineral exploration to delineate favorable targets for more detailed studies. Mineral deposits often occur in geochemical provinces characterized by elevated concentration of elements of economic interest and pathfinder 
elements. Ore deposits tend to cluster along specific stratigraphic units and/or structural trends over large areas. These geochemical data can be used in environmental studies, support decision makers in the definition of public policies and in the management of sustainable land use.

Keywords: geochemical mapping, stream sediment, Iron Quadrangle, mineral exploration, geological mapping.

\section{INTRODUCTION}

Geochemical mapping surveys give information about the behavior of chemical elements and their distribution in various geological environments and can be used in several applications, such as ore prospecting and in soil and water resource contamination assessment. The distribution and concentration of those chemical elements show significant variation, which is controlled by geological factors, biological (biogeochemical) processes and other kind of variables, such as anthropogenic activities (Darnley et al. 1995).

Regional scale geochemical mapping using soils and stream sediments samples have been carried out in several parts of world, mainly in Europe, Canada, Australia, USA and China. They aimed mineral exploration, natural resources evaluation and land management as well. Such subjects are used to the development of environmental policies and health and welfare studies of humans and biota.

The main interest of this project is to fill a gap in the geochemical knowledge of the Iron Quadrangle region, since it has great mineral potential as one of the most important mineral provinces of the world (Iron Quadrangle Mineral Province - IQMP); it is densely populated mainly at Belo Horizonte metropolitan area; and it presents different types of land use and occupation. The geochemical mapping of Iron Quadrangle region (IQ) intents to provide to the scientific and business communities geochemical data that support geological mapping and mineral exploration. Those data are also important for the implantation of environmental public policies in this region.

Therefore, the present geochemical mapping of IQ region by active stream sediment samples intents to stimulate the mineral exploration in this region, by characterizing the distribution and behavior of 53 chemical elements, with a consistent geochemical data base. This study also aims the improvement of protocols for the geochemical mapping surveys of Geological Survey of Brazil around the country. In order to attend the main aim of this study, some specific goals should be, namely: 1) establish, through systematic chemical analyses, the geochemical fingerprint correlated to the different rock types present in the study area, that is reflected in the sampled matrix, identifying the nature of bedrocks under the thick regolith cover; 2) describe the geochemical signature in stream sediments under the influence of the world wide known mineral deposits of IQ and search for those signatures in stream sediments in the same region. The IQ presents significant $\mathrm{Fe}$ and $\mathrm{Au}$ deposits (some of them classified as world class deposits), besides $\mathrm{Mn}$ and $\mathrm{Cr}$ ones and, in its surroundings, gemstone mineralization are also found (emerald and aquamarine). Such deposits display specific geochemical signatures in the regolith, which should be used when prospecting for new mineralized areas; 3) to identify some changes in the geochemical fingerprint of the mineral deposits due to surficial processes like weathering, erosion, transport and deposition, and supergene enrichment. Such processes, acting since the Late Cretaceous, could present different behavior of the chemical elements when compared to those in the primary mineralization and regional non weathered rocks. This fact is due to the extreme variety of lithological types and their specific weathering products, which display specific geochemical features, e.g., different background range for diverse geological materials. The comprehension of the elemental behavior could yield an efficient tool for the identification of potential mineral exploration targets.

The results of this work show that geochemical mapping can provide crucial information for the improvement of the geological knowledge, mineral exploration, environmental monitoring and studies for human health and development of public policies. Such subjects are of growing concern in the Brazilian governmental organizations, which care about the sustainable development of the country. The generated database is one of the most comprehensive of IQ. 


\section{STUDY AREA}

This research covers an area about 45,000 $\mathrm{km}^{2}$ and is located in south-center portion of Minas Gerais State (Figure 1). The boundaries of the study area were defined in order to embrace the IQMP, as well as some other portions of the São Francisco Craton and of the Mantiqueira Province (Araçuaí Orogen), yielding a polygon circumscribed by the coordinates $19^{\circ} 30^{\prime} \mathrm{S}$ to $21^{\circ} 00^{\prime} \mathrm{S}$ and $42^{\circ} 30^{\circ} \mathrm{W}$ to $45^{\circ} 00^{\circ} \mathrm{W}$.

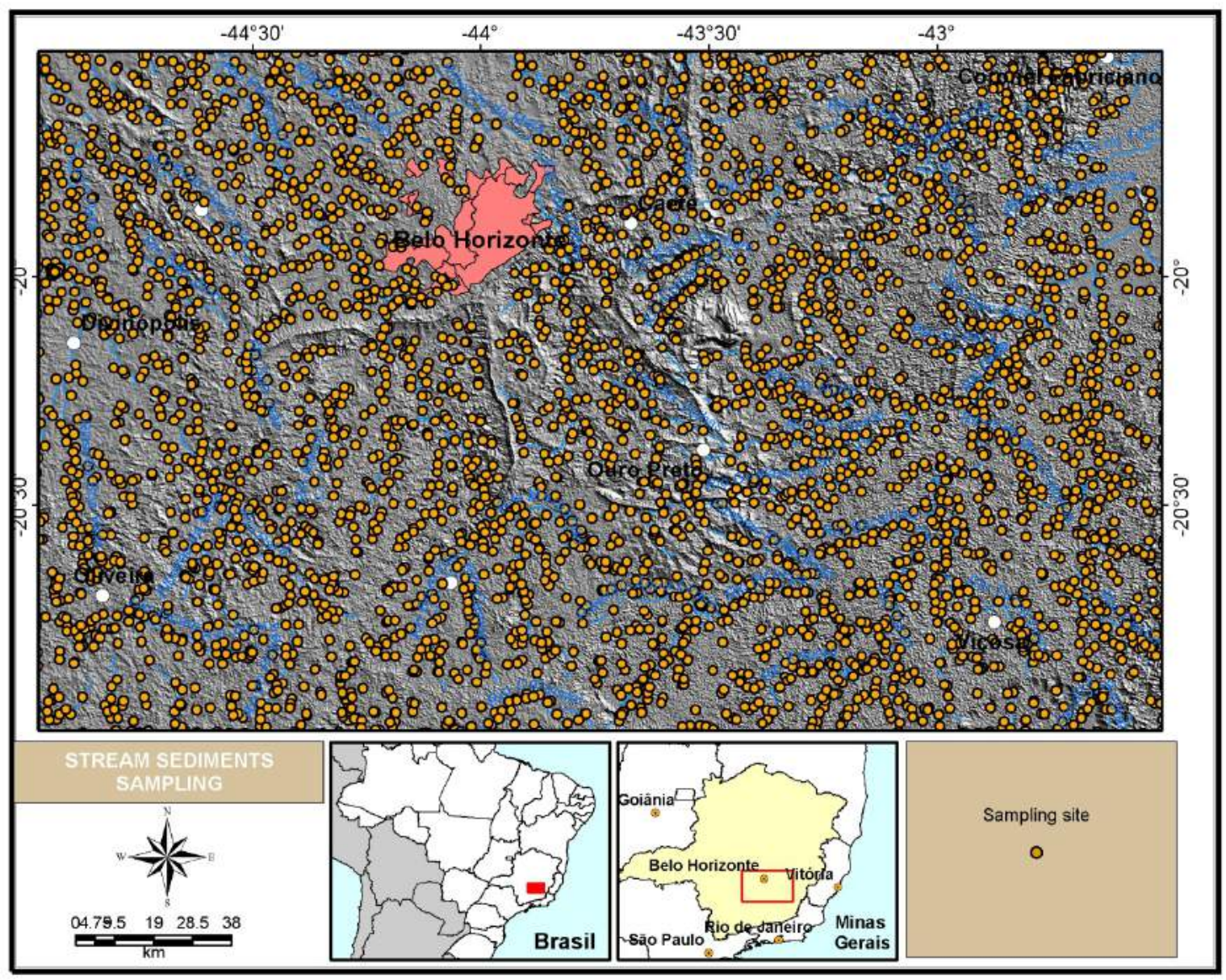

Figure 1

The IQ presents significant differences in its geomorphology, where the mountain ridges represent the weathering resistant rocks, like quartzite and itabirite, like Caraça Ridge, which reach about 2,000 meters above sea level. The central portion of the study area, the IQ itself, is limited by a set of 5 mountain ranges, namely, Curral Range at north, Moeda Range at west, Ouro Branco at south and Caraça and Gandarela Ranges at east. However, in its surroundings, the relief is more flattened, with elevations ranging between 800 and 1,000 meters, locally reaching 1,500 meters, at the eastern and southern portions, and 300 to 800 meters in the western portion, corresponding to the Doce River drainage basin. It is worth to notice that climate of the study area in the last $70 \mathrm{My}$ brought to the formation of the lateritic crusts, mainly on the itabiritic rocks (Spier 2005). These lateritic crusts have great importance in the relief development, once its stability to weathering processes protects some friable and erodible geological unities. Conversely, the IQ mountain ranges influence directly the weather of the study region, acting as barrier to the air masses and locally generating areas with different morphoclimatic systems (Barbosa \& Rodrigues 1967).

According to IBGE (2006a), the study region is inserted in the "Central Brazil Tropical Climate" zone, presents different climatic features, such as 1) mesothermic climate (semi-humid to humid; average temperature between $10^{\circ} \mathrm{C}$ and $15^{\circ} \mathrm{C}, 3$ to 5 dry months/year); 2) sub-warm climate (semi- arid 
to humid; average temperature between $15^{\circ} \mathrm{C}$ and $18^{\circ} \mathrm{C}, 1$ to 6 dry months/year); 3) warm climate (semi- humid; average temperature higher than $18^{\circ} \mathrm{C}, 4$ to 5 dry months/year). The driest period is concentrated in the winter and the wettest in the summer.

The hydrography of IQ is composed by 6 main catchment basins, namely, Doce, Piracicaba, Velhas, Paraopeba, Pará and Paraná rivers, with Doce and Paraopebas rivers being the most expressive basins in the study area. The Velhas River has its streams distribution to north-northwestward of the area, forming the more influent drainage basin in IQ and its springs rise in Ouro Branco and Caraça mountain ranges. Those ridges, together with Gandarela mountain range, are the main interfluves to Doce River drainage basin, located at east, while the Moeda Ridge is the main interfluve at west, which separates it from the Paraopebas drainage basin. Compared to the other basins in the IQ, the Velhas drainage network markedly displays greater structural control of its streams, which are characterized by deep and narrow valleys. The Doce basin, with its two main tributary streams, Piranga and Carmo rivers, sets up an arrangement from southwest to northeast, with flow direction to northeast. The streams of Doce River basin present more dissected and opened pattern, with lesser depth and structural control, as well as Paraopebas and Paraná river drainage basins. The Paraopebas River drainage basin shows its streams aligned from south-southeast to north-northwest, almost parallel to Velhas drainage basin. The Pará River drainage basin, right river bank tributary of São Francisco River, presents its streams flowing northwestward, where the São João and Peixe rivers are the main tributaries. The Paraná River basin, which has the smallest area in the study region (at southwest), shows its streams flowing south-southeastward. Its main tributaries in the study area are Jacaré and Perapetinga rivers (Barbosa \& Rodrigues 1967).

In a systematic geochemical mapping sur-

\section{GEOLOGY SUMMARY}

A simplified geologic sketch of the area is shown in Figure 2. Crystalline rocks range in age from Archean to Neoproterozoic. Archean terranes are composed mainly by granitoid/gneiss rocks of different composition, by (meta-)volcanic/sedimentary sequences (Rio das Velhas and other vey, it must be taken into account the land use of the present days and also from the past of the study region, in order to characterize the influence of the anthropogenic processes, which affect the geochemical distribution and behavior of chemical elements in the environment (Darnley et al. 1995). The land use and management of IQ started in the 1800 's, with the discovery of gold deposits, which trigged the formation of several villages. Nevertheless, the economic development of Minas Gerais State was unorganized and discontinuous (De Paula 2002). Up to the middle of 1800 's, in IQ, the highlighted activities were the mercantile economy of primary necessities, coffee plantation and the start of informal steel industry. At this period, the gold exploitation experienced ups and downs, with the depletion of alluvial deposits. It should be notice that all the industrial sectors presented above were developed by slave labor. The State of Minas Gerais industry had another expansion in the 1940-50's, trigged by the State of São Paulo economy growth, with modern steel and cement industries. At the postwar period, it was initiated in the State of Minas Gerais the modern metallurgic industry, highlighting the IQ, due to its natural resources (base metal deposits) allied to foreign investment.

According to IBGE (2010), the study region presents several land uses, highlighting farming activities (mainly cattle breeding), which occupies $70 \%$ of the area. The native vegetation occupies the second place in land use; it is composed by the transition between Cerrado and Atlântica forests, whose distribution is discontinuous due to the urban cores. This native vegetation makes up about $20 \%$ of the area, while the urban cores correspond to $6 \%$, highlighting Belo Horizonte Metropolitan Region. In spite of the environmental and visual impacts caused by mining activities, it corresponds to only $3 \%$ of the study region. It should be noticed that native vegetation is highly preserved when one considers the whole mining properties.

greenstone belts) and by mafic/ultramafic intrusives. Intrusive rocks of granitic and basic affinities and metasedimentary sequences characterize Paleoproterozoic and Mesoproterozoic units. Neoproterozoic units are composed of metamorphic rocks of various origins and carbonate-rich sediments. 
Cenozoic sedimentary and lateritic covers overlain older rocks locally.

Archean supracrustal rocks were polydeformed and polymetamorphosed from Archean to Paleoproterozoic with a metamorphic peak at amphibolite facies and retrograde metamorphism at green schist facies. Baltazar \& Zucchetti (2007) claim that the first-generation structures present at Rio das Velhas greenstone belt are Late Archean in age; the last ones are of Neoproterozoic age. A study of P-T conditions in rocks of Nova Lima Group is indicative of low geothermic gradient and suggest a plate tectonic environment with a collision process followed by orogenic collapse associated with a extensional zone at Transamazonian times (Coelho 2015).

The eastern portion of the studied region is formed by rocks of Araçuaí Fold Belt (Almeida 1977), later defined as orogenic belt of Neoproterozoic age by Pedrosa-Soares \& Wiedmann-Leonardos (2000). It is characterized by supracrustal rocks metamorphosed and deformed at greenschist and low amphibolite facies. The supracrustal rocks were deposited in a rift-type basin where one can observe, at the studied area, quartzites and conglomerates, diamictites, turbidites, iron formations (Rapitan-type and oxide-type), quartz-mica schists, calc-silicate rocks, graphite schists and marbles (Heilbron et al. 2004). Lateritic and alluvial covers occur in restricted areas.

The Iron Quadrangle region is one of the major iron, manganese, gold and gemstone producers in Brazil. Figure 2 shows the location of some of the main deposits. Iron and manganese deposits are associated with "itabirito" rocks (Banded Iron Formation BIF) of Proterozoic age that form the "Iron Quadrangle". Gemstone deposits are related to pegmatites located in the northeast of the study area. Most of the gold is associated with Archean or Paleoproterozoic carbonate- or BIF sequences. The Morro Velho mine (including Mina Velha and Mina Grande) produced more than $500 \mathrm{t}$ of gold (Bierlein et al. 2006); other major deposits are Cuiabá and Raposos.

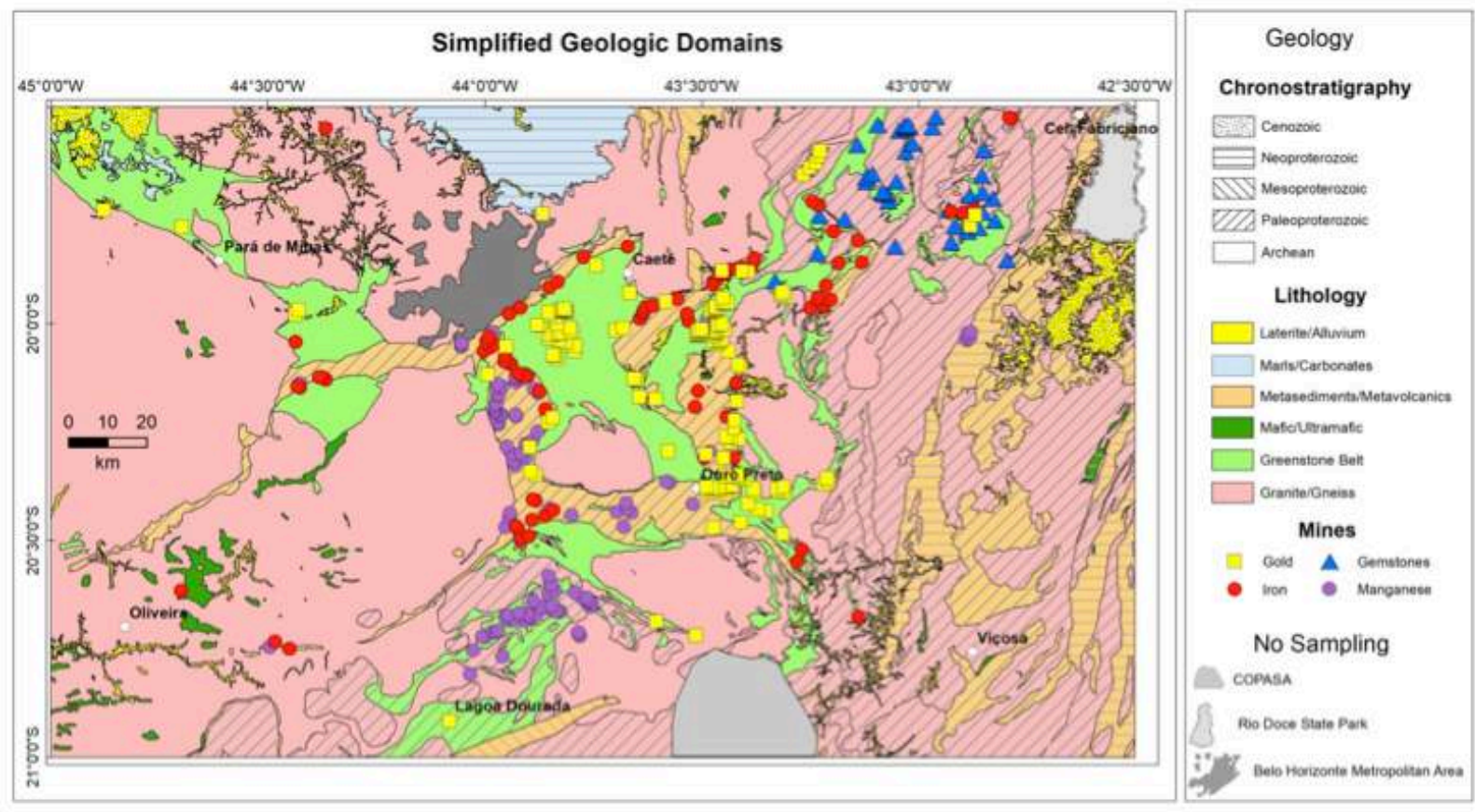

Simplified geological domains and active mines of the studied area. In gray, areas not sampled.

\section{MATERIAL AND METHODS}

The sampling of stream sediment was planned in catchment basins between 10 and $30 \mathrm{~km}^{2}$ (Figure 1). The stream network of the study area was based in IBGE topographic charts, in a scale of $1: 100,000$, adjusted to GEOCOVER images. The sampling stations were defined at the lowest altitude point of each drainage basin (downstream), and taking 
into account the influence of neighbor streams, roads, bridges and anthropogenic activities, in order to avoid the contamination vectors to the samples. Altogether 3,662 samples were collected, with an average sample density of 1 sample/12 $\mathrm{km}^{2}$. In some areas, like Belo Horizonte Metropolitan Region (at the northern portion of the area) and other urban nuclei, the COPASA area (at south) and the Rio Doce National Park (at northeast), there was no sample collection due to high contaminated (sewage and industrial waste) or inaccessible areas.

The grain size fraction chosen for analysis was set at $<80 \#(0,175 \mathrm{~mm}$, ranging from thin sand to clay) and the minimum amount of sampled material was $1 \mathrm{~kg}$ of original material. This grain fraction range was chosen because it was established as a standard for the geochemical mapping surveys performed by the Geological Survey of Brazil since the 1970 's and it is important in order to make comparison to other areas in the country. Besides, this fraction has greater potential to enhance the contrast of some elements compared to other coarse fraction, mainly trace metals, due to highest adsorption specific area (Levinson 1974, Rose et al. 1978, Licht 1998). During fieldwork, each sample was collect at 5 to 10 different spots at the same sampling site along 50 meters of the stream channel, in order to give representativeness to the sampled material. For the same purpose, a plastic sieve of about $1 \mathrm{~mm}$ was used to avoid significant amount of coarse grains and plants fragments. Before and after sampling all sampling tools (sieve, plastic spoon, etc.) were washed with the water of the sampling site. In cases of possible contamination by an anthropogenic source (as commented before) or even from the river banks, the sampling stations were relocated at least $25 \mathrm{~m}$ upstream or even excluded in the most critical cases.

The samples were treated in the sample preparation laboratory of the Geological Survey of Brazil, located at Caeté, State of Minas Gerais. The samples were dried at room

\section{RESULTS}

The Exploratory Data Analysis (EDA) was carried out in 2 stages: 1) univariate and bivariate statistics and 2) multivariate statistics. In the first stage, the variables are singly examined and all log- transformed in order to compensate the asymmetrical temperature (to avoid the loss of some elements, like $\mathrm{Hg}$ and $\mathrm{As}$ ), disaggregated in porcelain mortar, sieved $<80 \#$, and a portion of $50 \mathrm{~g}$ separated for chemical analysis. All the surplus material was preserved in order to assemble the project memory. The chemical analyses were carried out by ACME Labs, Vancouver, Canada. The sampled were pulverized to $150 \#(\sim 0.1 \mathrm{~mm})$, digested by hot acqua regia (in the proportion of $2 \mathrm{HNO}_{3}$ $2 \mathrm{HCl}-2 \mathrm{H}_{2} \mathrm{O}$ ) and analyzed by inductively coupled plasma mass spectrometry (ICP-MS).

The analytical precision was calculated by the variation coefficients of duplicate analytical samples, which demonstrated that some elements, namely, $\mathrm{Be}, \mathrm{Ga}, \mathrm{Ge}, \mathrm{Hf}, \mathrm{K}$, $\mathrm{Mg}, \mathrm{P}, \mathrm{Pt}, \mathrm{Re}, \mathrm{S}, \mathrm{Sc}, \mathrm{Se}, \mathrm{Sn}, \mathrm{Ta}, \mathrm{Te}, \mathrm{Th}, \mathrm{U}, \mathrm{V}$, $\mathrm{W}, \mathrm{Zr}$, had irregular results $(>15 \%)$ due to the chemical digestion applied in this study. The analytical accuracy was determined with an internal reference material of ACME Labs (Standard DS7) and with the reference material São Joaquim 2709, provided by NIST, whose results demonstrate a satisfactory recovery for the most analyzed elements, ranging from $80 \%$ to $90 \%$.

The data generated in this study were incorporated to the GEOSGB database of the Geological Survey of Brazil. The spatial data analysis was carried out using the geographic information system package ESRI ArcMap ${ }^{\circledR}$ (ESRI, 2011), the statistical treatment was performed using Statistica V10 (StatSoft, Inc. 2011) and the design of geochemical maps with Geosoft Oasis Montaj V7.3 (Jy) SP2 (Geosoft Inc. Copyright ${ }^{\circledR}$ 2011). The procedure of the exploratory data analysis (EDA) adopted in this research was established by Grunsky (2007, 2010), Reimann et al. (2002, 2008) and Carranza (2009). The analytical results for every element lower than the detection limit $(<\mathrm{DL})$ of the analytical method were replaced by the half of its indicated concentration value, in order to allow the statistical treatment (like data transformations, e.g. log-normalization).

distribution. Associations of chemical elements were assessed using correlation coefficients. In this analysis, the outliers were excluded using Box-Whisker plots, with the purpose to avoid false correlations. In the second stage, the logtransformed data were assessed by Factor 
Table 1 - Descriptive statistics for the elements analyzed in the stream sediment samples.

\begin{tabular}{|c|c|c|c|c|c|c|c|c|c|c|}
\hline Variable & Valid N & Min & $10 \%$ & $25 \%$ & Median & Mean & $75 \%$ & $90 \%$ & Max & Std. Deviation \\
\hline $\mathrm{Ag}(\mathrm{ppb})$ & 3662 & 2 & 10 & 15 & 21 & 28.62 & 30 & 42 & 2409 & 60.05 \\
\hline $\mathrm{Al}(\%)$ & 3662 & 0.12 & 0.88 & 1.41 & 2.13 & 2.37 & 3.07 & 4.19 & 9.85 & 1.36 \\
\hline As (ppm) & 3662 & 0.05 & 0.4 & 0.8 & 1.5 & 7.08 & 3.9 & 14 & 1665 & 34.79 \\
\hline $\mathrm{Au}(\mathrm{ppb})$ & 3662 & 0.1 & 0.2 & 0.4 & 0.8 & 50.56 & 1.6 & 3.6 & 56989.9 & 1311.96 \\
\hline $\mathrm{B}(\mathrm{ppm})$ & 3662 & 10 & 10 & 10 & 10 & 10.28 & 10 & 10 & 49 & 2.88 \\
\hline $\mathrm{Ba}(\mathrm{ppm})$ & 3662 & 3.7 & 32.7 & 51.1 & 76.5 & 92.65 & 112.3 & 160.6 & 4317.4 & 100.41 \\
\hline $\mathrm{Be}(\mathrm{ppm})$ & 3662 & 0.05 & 0.2 & 0.4 & 0.5 & 0.61 & 0.8 & 1.1 & 5.3 & 0.39 \\
\hline $\mathrm{Bi}(\mathrm{ppm})$ & 3662 & 0.01 & 0.04 & 0.07 & 0.15 & 0.24 & 0.29 & 0.51 & 10.09 & 0.36 \\
\hline $\mathrm{Ca}(\mathrm{ppm})$ & 3662 & 0.01 & 0.02 & 0.03 & 0.05 & 0.08 & 0.08 & 0.12 & 9.54 & 0.22 \\
\hline $\mathrm{Cd}(\mathrm{ppm})$ & 3662 & 0.01 & 0.01 & 0.02 & 0.03 & 0.04 & 0.05 & 0.08 & 4.1 & 0.08 \\
\hline $\mathrm{Ce}(\mathrm{ppm})$ & 3662 & 1.5 & 24.7 & 39 & 63.2 & 83.02 & 99.2 & 148.8 & 1105 & 82.57 \\
\hline Co (ppm) & 3662 & 0.2 & 3 & 5.4 & 10.3 & 15.33 & 18.4 & 31.1 & 894.6 & 23.51 \\
\hline $\mathrm{Cr}(\mathrm{ppm})$ & 3662 & 0.9 & 12 & 27.2 & 54.5 & 84.27 & 96.3 & 167.9 & 7003.5 & 179.57 \\
\hline Cs (ppm) & 3662 & 0.02 & 0.23 & 0.43 & 0.82 & 1.02 & 1.32 & 2.03 & 8.3 & 0.88 \\
\hline $\mathrm{Cu}(\mathrm{ppm})$ & 3662 & 0.32 & 5.89 & 9.98 & 17.93 & 22.21 & 28.38 & 42.21 & 424 & 19.41 \\
\hline $\mathrm{Fe}(\%)$ & 3662 & 0.13 & 1.84 & 3.01 & 4.61 & 5.80 & 6.89 & 10.35 & 80 & 4.99 \\
\hline $\mathrm{Ga}(\mathrm{ppm})$ & 3662 & 0.5 & 4.1 & 6.7 & 10.1 & 10.72 & 14.1 & 17.9 & 51.8 & 5.53 \\
\hline $\mathrm{Ge}(\mathrm{ppm})$ & 3662 & 0.05 & 0.05 & 0.05 & 0.05 & 0.07 & 0.05 & 0.05 & 1.9 & 0.09 \\
\hline $\mathrm{Hf}(\mathrm{ppm})$ & 3662 & 0.01 & 0.03 & 0.05 & 0.09 & 0.12 & 0.15 & 0.23 & 2.05 & 0.14 \\
\hline $\mathrm{Hg}(\mathrm{ppm})$ & 3662 & 2 & 11 & 19 & 35 & 47.07 & 63 & 93 & 2136 & 57.65 \\
\hline In (ppm) & 3662 & 0.01 & 0.02 & 0.02 & 0.04 & 0.04 & 0.06 & 0.08 & 0.52 & 0.03 \\
\hline K (\%) & 3662 & 0.01 & 0.02 & 0.05 & 0.08 & 0.10 & 0.14 & 0.2 & 1.13 & 0.08 \\
\hline $\mathrm{La}(\mathrm{ppm})$ & 3662 & 0.6 & 6.7 & 11.6 & 20.7 & 30.63 & 36 & 59.6 & 673.8 & 39.12 \\
\hline $\mathrm{Li}(\mathrm{ppm})$ & 3662 & 0.1 & 1.6 & 2.9 & 4.9 & 6.09 & 7.9 & 11.6 & 50.9 & 4.78 \\
\hline $\operatorname{Mg}(\%)$ & 3662 & 0.01 & 0.02 & 0.04 & 0.08 & 0.11 & 0.14 & 0.22 & 6.3 & 0.15 \\
\hline $\mathrm{Mn}(\mathrm{ppm})$ & 3662 & 13 & 147 & 262 & 490 & 866.08 & 948 & 1869 & 20000 & 1267.30 \\
\hline Mo (ppm) & 3662 & 0.03 & 0.19 & 0.29 & 0.45 & 0.75 & 0.71 & 1.24 & 16.08 & 1.15 \\
\hline $\mathrm{Na}(\%)$ & 3662 & 0 & 0 & 0 & 0 & 0.00 & 0.01 & 0.01 & 0.22 & 0.01 \\
\hline $\mathrm{Nb}(\mathrm{ppm})$ & 3662 & 0.01 & 0.16 & 0.28 & 0.51 & 0.83 & 0.88 & 1.4 & 34.67 & 1.62 \\
\hline $\mathrm{Ni}(\mathrm{ppm})$ & 3662 & 0.2 & 3.6 & 7.3 & 13.5 & 23.36 & 25.2 & 48.4 & 2238.3 & 50.39 \\
\hline $\mathrm{P}(\%)$ & 3662 & 0 & 0.01 & 0.02 & 0.03 & 0.04 & 0.05 & 0.07 & 0.5 & 0.03 \\
\hline $\mathrm{Pb}(\mathrm{ppm})$ & 3662 & 1.23 & 8.43 & 12.14 & 17.455 & 18.99 & 23.43 & 30.97 & 114.91 & 10.04 \\
\hline $\mathrm{Pd}(\mathrm{ppb})$ & 3662 & 1 & 10 & 10 & 10 & 14.70 & 10 & 27 & 383 & 18.76 \\
\hline $\mathrm{Pt}(\mathrm{ppb})$ & 3662 & 1 & 1 & 2 & 2 & 2.40 & 2 & 4 & 34 & 1.79 \\
\hline $\mathrm{Rb}(\mathrm{ppm})$ & 3662 & 0.1 & 3 & 6.3 & 12.4 & 15.70 & 20.8 & 32.3 & 132 & 13.63 \\
\hline $\operatorname{Re}(p p b)$ & 3662 & 0.5 & 0.5 & 1 & 1 & 0.89 & 1 & 1 & 4 & 0.26 \\
\hline S (\%) & 3662 & 0.01 & 0.01 & 0.01 & 0.01 & 0.02 & 0.01 & 0.03 & 3.08 & 0.05 \\
\hline $\mathrm{Sb}(\mathrm{ppm})$ & 3662 & 0.01 & 0.02 & 0.02 & 0.04 & 0.46 & 0.12 & 0.53 & 141.27 & 3.13 \\
\hline $\mathrm{Sc}(\mathrm{ppm})$ & 3662 & 0.2 & 2.1 & 3.5 & 6.1 & 7.23 & 9.8 & 13.8 & 39 & 5.00 \\
\hline $\mathrm{Se}(\mathrm{ppm})$ & 3662 & 0.05 & 0.1 & 0.2 & 0.3 & 0.35 & 0.5 & 0.6 & 20.4 & 0.40 \\
\hline $\mathrm{Sn}(\mathrm{ppm})$ & 3662 & 0.1 & 0.6 & 1 & 1.6 & 2.08 & 2.5 & 3.8 & 26.3 & 2.00 \\
\hline $\mathrm{Sr}(\mathrm{ppm})$ & 3662 & 0.5 & 2.4 & 3.8 & 6 & 8.24 & 9.4 & 14.7 & 506.1 & 12.59 \\
\hline $\mathrm{Ta}(\mathrm{ppm})$ & 3662 & 0.025 & 0.025 & 0.025 & 0.025 & 0.03 & 0.025 & 0.025 & 0.17 & 0.00 \\
\hline $\mathrm{Te}(\mathrm{ppm})$ & 3662 & 0.01 & 0.01 & 0.02 & 0.02 & 0.03 & 0.03 & 0.05 & 1.32 & 0.03 \\
\hline Th (ppm) & 3662 & 0.2 & 4.2 & 6.9 & 12.3 & 17.86 & 21.4 & 35.7 & 339.3 & 21.48 \\
\hline Ti (\%) & 3662 & 0 & 0.01 & 0.03 & 0.05 & 0.06 & 0.08 & 0.11 & 0.33 & 0.04 \\
\hline $\mathrm{Tl}(\mathrm{ppm})$ & 3662 & 0.02 & 0.06 & 0.1 & 0.18 & 0.22 & 0.28 & 0.42 & 1.5 & 0.16 \\
\hline $\mathrm{U}(\mathrm{ppm})$ & 3662 & 0.1 & 0.7 & 1.1 & 1.9 & 2.65 & 3.3 & 5.6 & 32.9 & 2.47 \\
\hline $\mathrm{V}(\mathrm{ppm})$ & 3662 & 1 & 17 & 31 & 58 & 67.72 & 93 & 130 & 407 & 48.07 \\
\hline $\mathrm{W}(\mathrm{ppm})$ & 3662 & 0.05 & 0.05 & 0.05 & 0.05 & 0.08 & 0.05 & 0.05 & 14.8 & 0.28 \\
\hline $\mathrm{Y}(\mathrm{ppm})$ & 3662 & 0.38 & 2.86 & 4.86 & 8.45 & 10.62 & 13.65 & 20.21 & 110.3 & 8.80 \\
\hline $\mathrm{Zn}(\mathrm{ppm})$ & 3662 & 1.3 & 15.2 & 22 & 31.3 & 36.59 & 43 & 57.4 & 1926.8 & 42.76 \\
\hline $\mathrm{Zr}(\mathrm{ppm})$ & 3662 & 0.2 & 1.3 & 2 & 3.6 & 5.15 & 6.2 & 9.9 & 78.8 & 5.75 \\
\hline
\end{tabular}

Analysis (R-mode) using Principal Component Analysis for factor extraction (considering the total variance of the data system) and with a Varimax normalized rotation. The use of those statistical tools allow to investigate the structure, trends and associations of the analyzed elements, helping in the comprehension of geological, physical and anthropogenic processes that controls the sampling environment (Manly 1986, Davis 
1986, Tabachnick \& Fidell 2001, Reimann et al. 2002, Reimann et al. 2008, Filzmoser et al. 2009, Carranza 2009, Grunsky 2010, Lapworth et al. 2012).

The results of geochemical data of 53 elements and some statistical parameters of the variables are presented in Table 1; Figures 3 and 4 show histograms and probability plots for these data.

The analysis of the Histograms (Figure 3), Probability plots (Figure 4) shows the need to remove some elements to elaborate the Principal Component Analysis (PCA); these are: $\mathrm{B}, \mathrm{Be}, \mathrm{Bi}, \mathrm{Ca}, \mathrm{Cd}, \mathrm{Ge}, \mathrm{Hf}, \mathrm{In}, \mathrm{K}, \mathrm{Mg}, \mathrm{Mo}$, $\mathrm{Na}, \mathrm{Nb}, \mathrm{P}, \mathrm{Pd}, \mathrm{Pt}, \mathrm{Re}, \mathrm{S}, \mathrm{Sb}, \mathrm{Se}, \mathrm{Ta}, \mathrm{Te}, \mathrm{Ti}, \mathrm{Tl}$ and $\mathrm{W}$. These elements show many results below Detection Limit (DL) and/or censored data. For this reason, those data were not assessed in bivariate and PCA treatment stages.

The distribution of the selected elements is shown on individual maps (Figure 5), where the punctual results (sampling stations) are plotted over a background image which shows the variation of concentration of each element as a continuous interpolated surface; the color scale ranges from the dark blue to magenta- representing, respectively, lower to higher element contents.

Some elements mark the presence of IQ due to its intense contrast in relation to the surrounding lithologies (e.g., higher values for $\mathrm{As}, \mathrm{Au}$; and lower values for $\mathrm{Ce}, \mathrm{Cs}, \mathrm{Rb}, \mathrm{U}$ and $\mathrm{Y}$ ). The concentration contrasts of other elements, e.g., $\mathrm{Ce}$ and $\mathrm{Zr}$, characterize the boundary between the São Francisco craton and the mobile belt to the East. Evolved granitic rocks and pegmatites are evidenced by high concentrations of $\mathrm{Al}, \mathrm{Ce}, \mathrm{Cs}, \mathrm{La}, \mathrm{Pb}, \mathrm{Rb}$, Th, U and Y (e.g., Borrachudos Suite). High values of $\mathrm{Co}, \mathrm{Cr}, \mathrm{Cu}$ and $\mathrm{Ni}$ are observed over mafic and ultramafic rocks (e.g., Nova Lima Group). These geochemical variations are illustrated in Figure 5.

Some elements show good correlation with the mineralization. For instance, the gold ore and well known pathfinder elements like Ag, $\mathrm{As}, \mathrm{Au}, \mathrm{Fe}, \mathrm{Mn}$ and Sb. Zinc, a traditional gold pathfinder, on the other hand, show weak spatial correlation with known gold deposits (Figure 6). Gemstones mineralization is also correlated with some elements, like Bi and $\mathrm{Sn}$ (Figure 7). Figure 8 shows the Correlation Plot for selected elements considered for PC analysis.

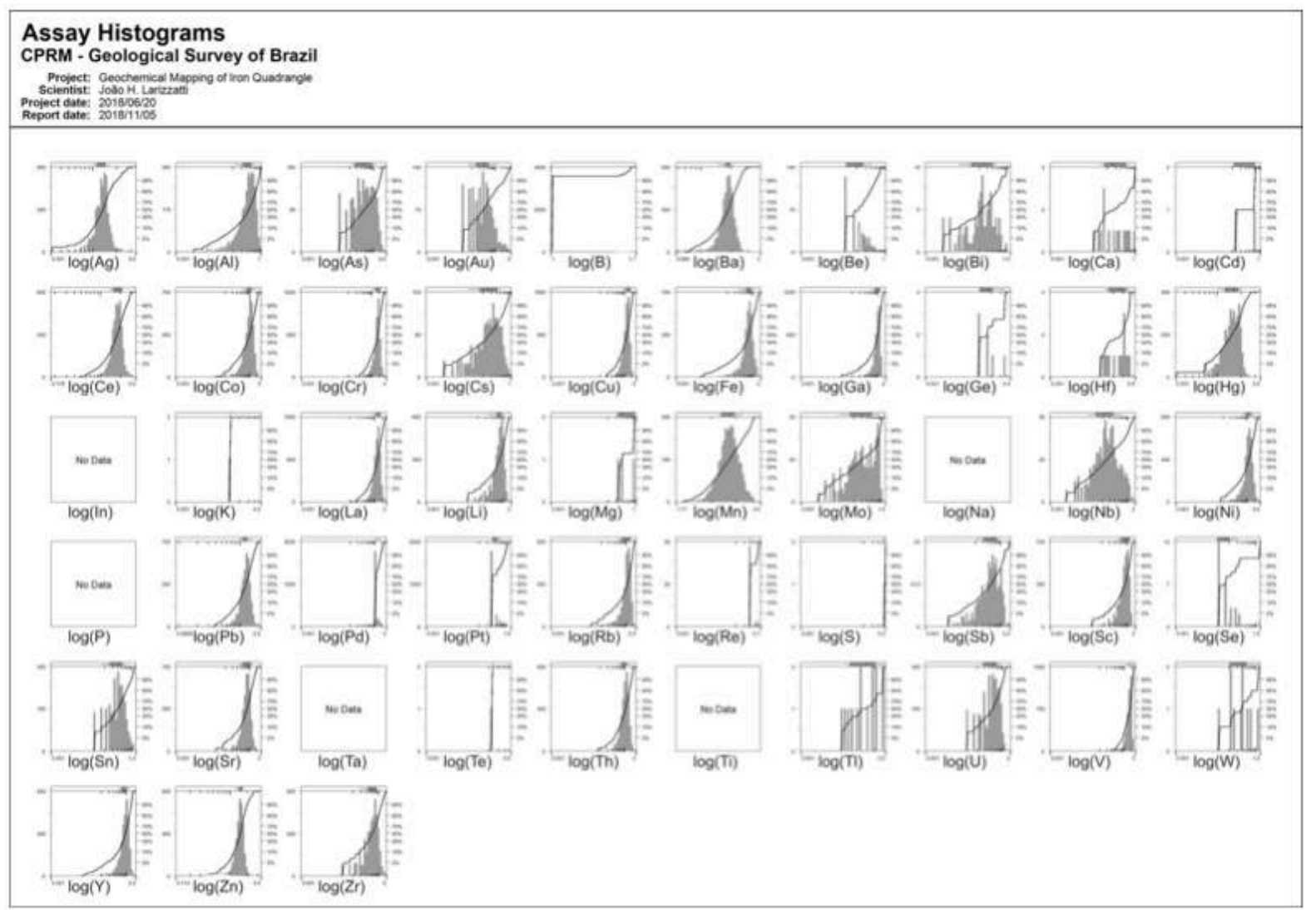

Figure 3 


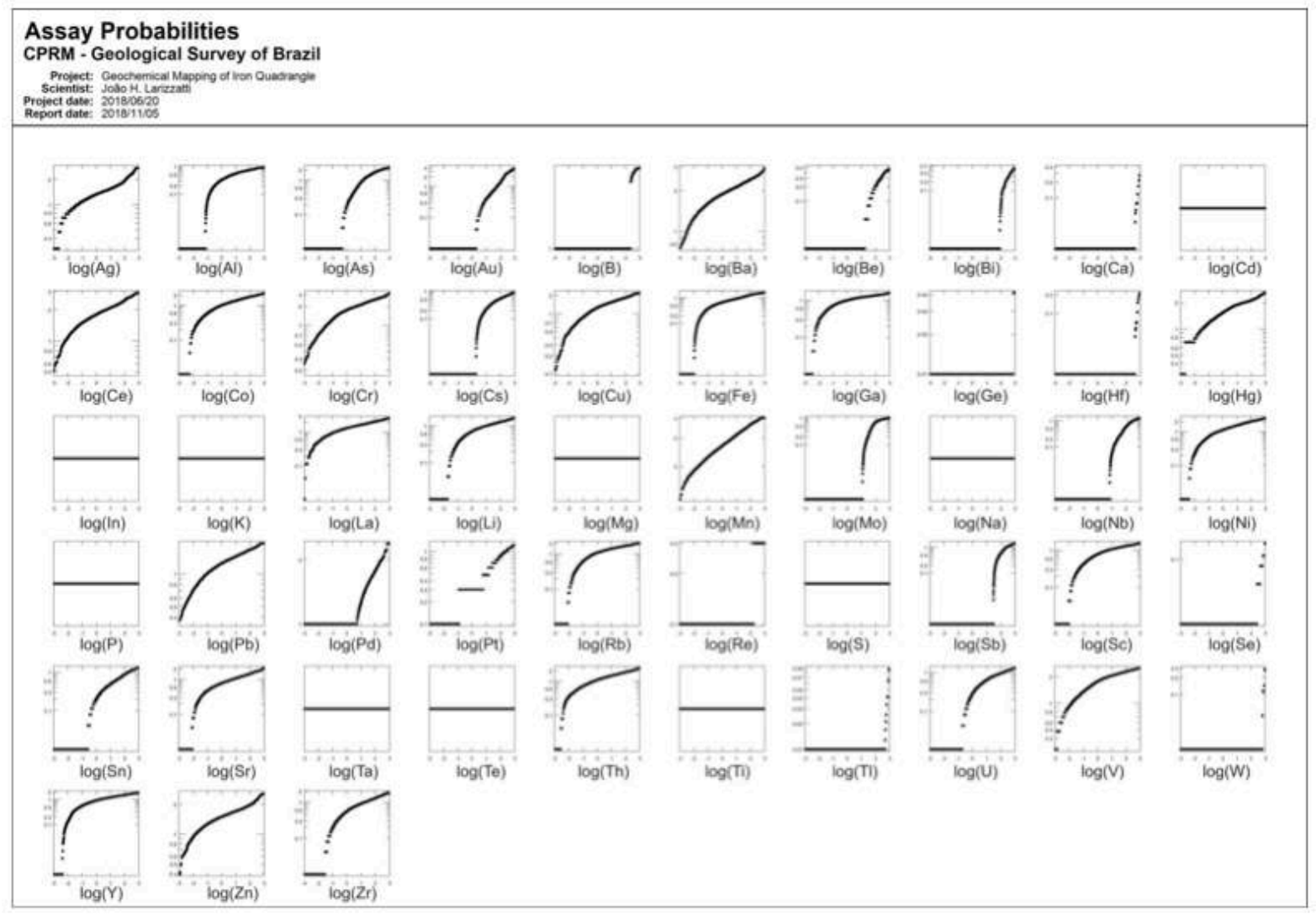

Figure 4

Probability plots for the elements analyzed in the stream sediment samples.

The Correlation Plots for selected elements (Figure 8) show:

1. Very strong correlation between (a) $[\mathrm{Cr}$ $\mathrm{Ni}-\mathrm{V}]$ and [V-Sc], elements associated, in general, with mafic and ultramafic rocks; and (b) [Ce-La], elements associated, in general, with some acid and/or alkaline rocks.

2. Strong correlation between (a) [Cr-Co$\mathrm{Cu}-\mathrm{Sc}]$, [Ni-Co-Cu-V], [Sc-Cr-Cu] and [V-Co-Cu-Ni], that are related, in general, to mafic and ultramafic rocks; and (b) [La-Rb-Th-Y], [Th-Ce-La-Pb] and [Y-Ce$\mathrm{La}$ ], that, in general, are related to acid and/or alkaline rocks; and (c) [ $\mathrm{Zn}-\mathrm{Co}-\mathrm{Cu}]$ that can be related to mafic rocks.

3. Moderate correlation between (a) [Fe-Co$\mathrm{Cr}-\mathrm{Cu}-\mathrm{Mn}-\mathrm{Ni}-\mathrm{Sc}-\mathrm{V}]$ that can be related to mafic and/or ultramafic rocks; (b) [Pb-LaRb-Sn-U-Y-Zn], [Li-Cs-Rb-Y-Zn] that can be related to acid/alkaline rocks.

4. Weak correlation was observed between [Au-Ag-As], that can indicate hydrothermal alteration and gold mineralization.
The geochemical associations of elements in the stream sediments, defined by Principal Component Analysis (PCA, Geosoft V7.3 (Jy) SP2 (Geosoft Inc. Copyright ${ }^{\circledR}$ 2011), were used as reference to the multielementar association and geochemical maps, presented in the Figures 9 to 18 , being considered only elements with loadings higher than 0.40 . An exception was made for the association [AuAg-As], traditionally used in gold exploration. The geological/geochemical behavior of the elements was interpreted according to the studies of Wedepohl (1976) and Amor (2011). The number of the Components in PCA was obtained by the number of eigenvalues, using the Kaiser criteria (considering only eigenvalues $>1$ ). The five factors obtained by PCA, provide a better understanding of the elements behavior in relation to the geological processes present at the study region. Figures 10, 12, 14, 16 and 18 show Factor Scores distribution in the studied area. These five factors correspond to $70.4 \%$ of total system variance (Table 2). 

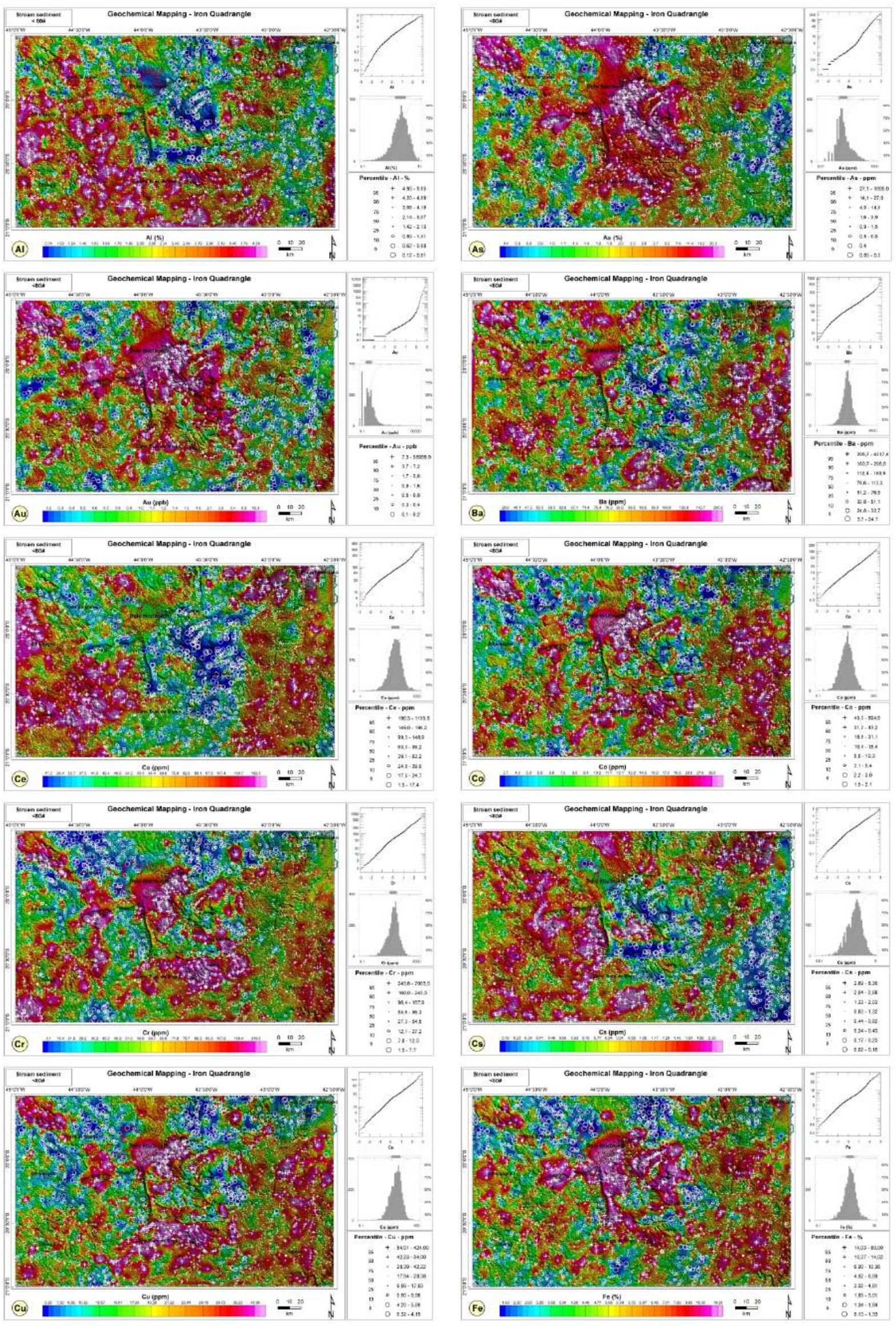

Geochemical maps for $\mathrm{Al}, \mathrm{As}, \mathrm{Au}, \mathrm{Ba}, \mathrm{Ce}, \mathrm{Co}, \mathrm{Cr}$, Cs, Cu and Fe. 

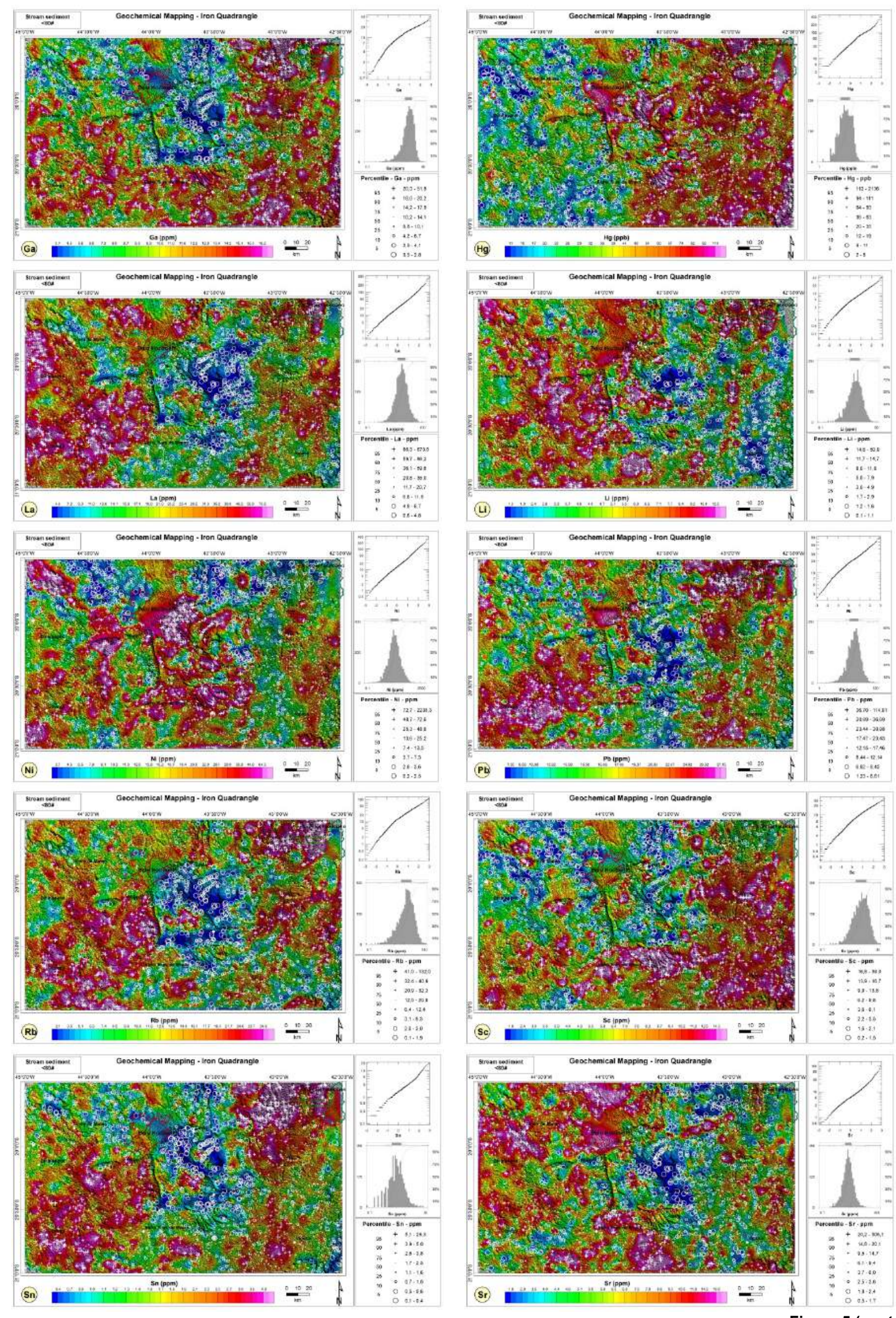

Figure 5 (cont)

Geochemical maps for $\mathrm{Ga}, \mathrm{Hg}$, La, Li, Ni, Pb, Rb, Sc, Sn and Sr. 

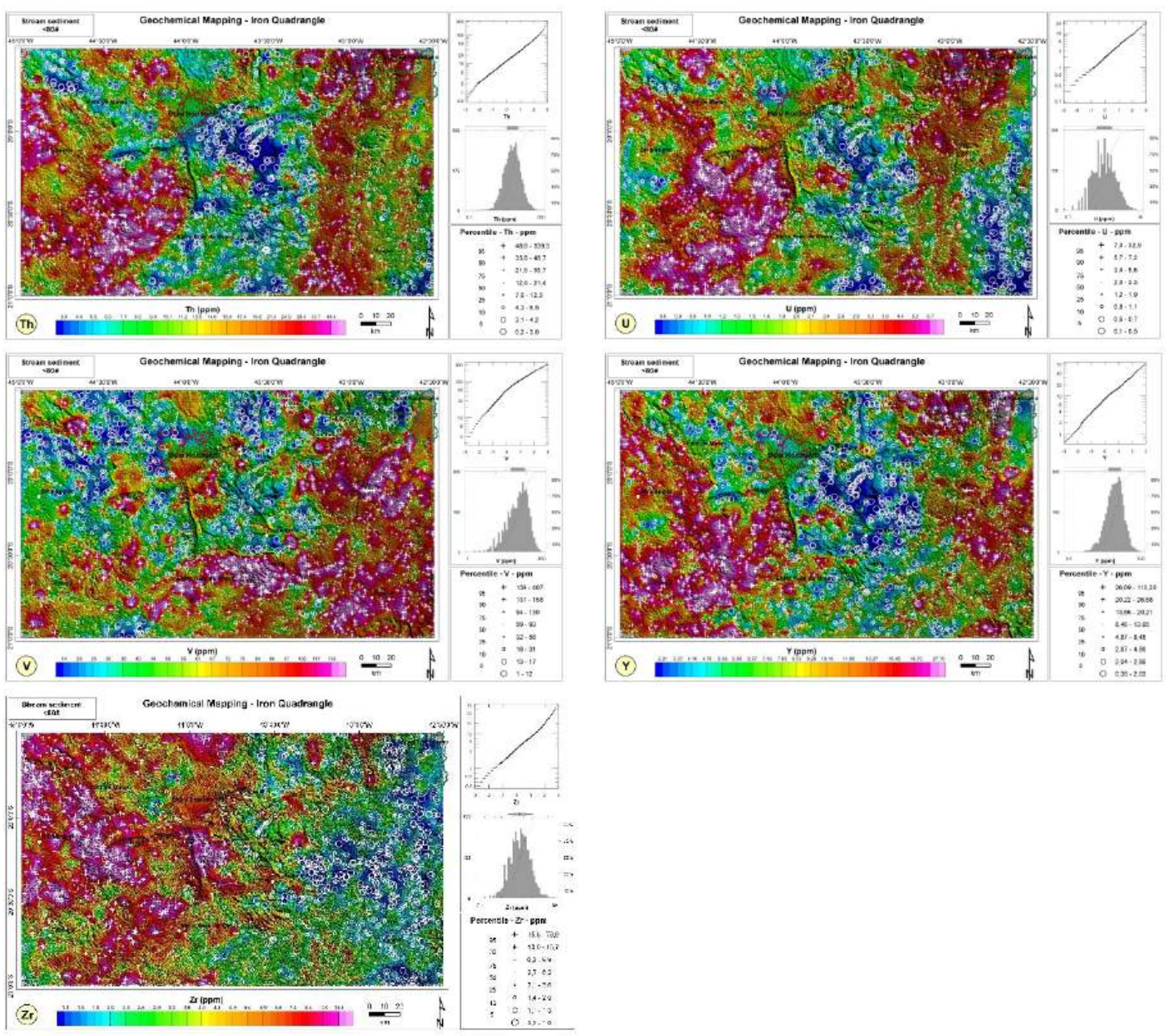

Figure 5 (cont.) Geochemical maps for Th, U, V, Y and Zr.
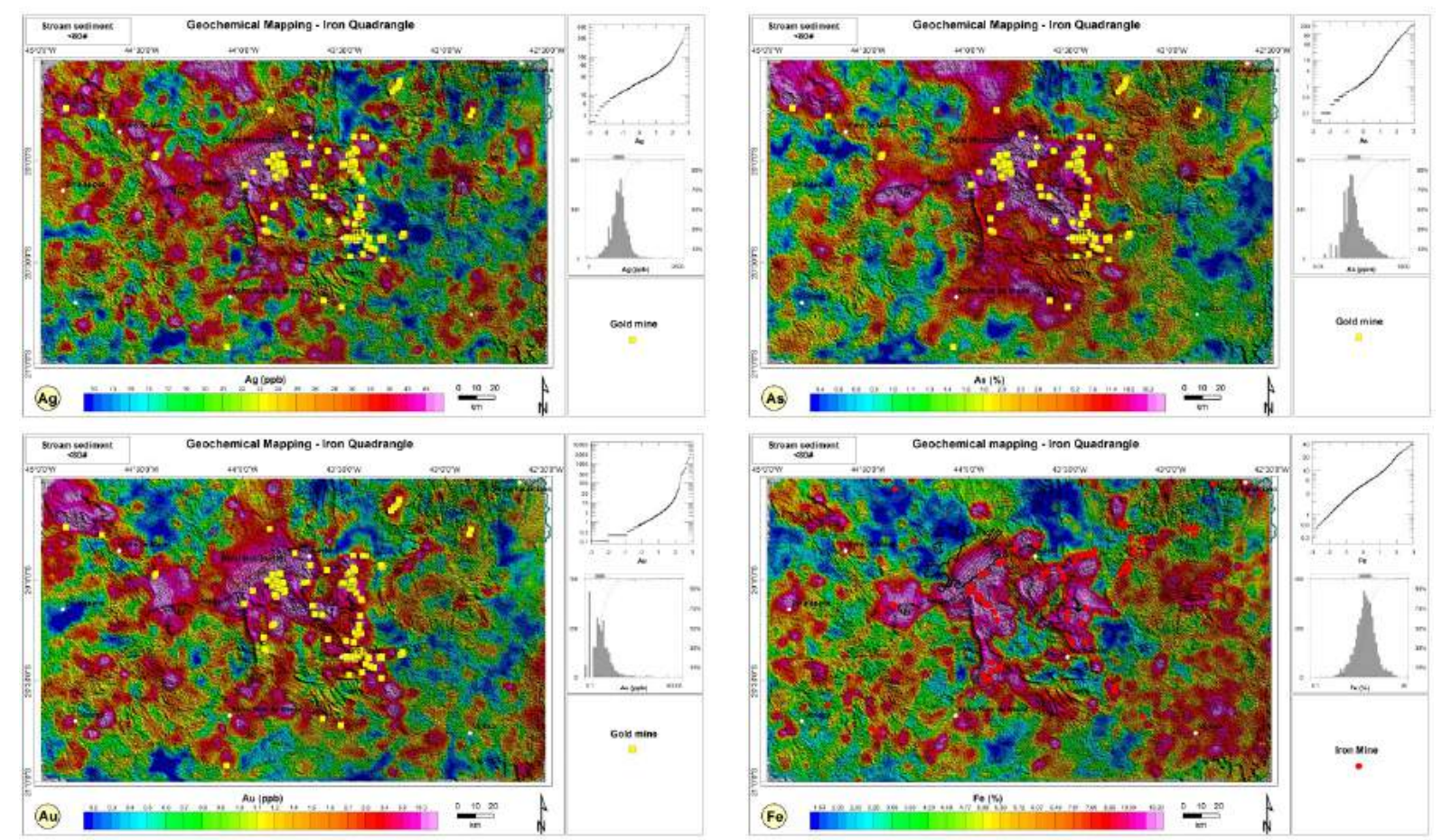

Figure 6

Selected pathfinder elements and known gold deposits and mines. 

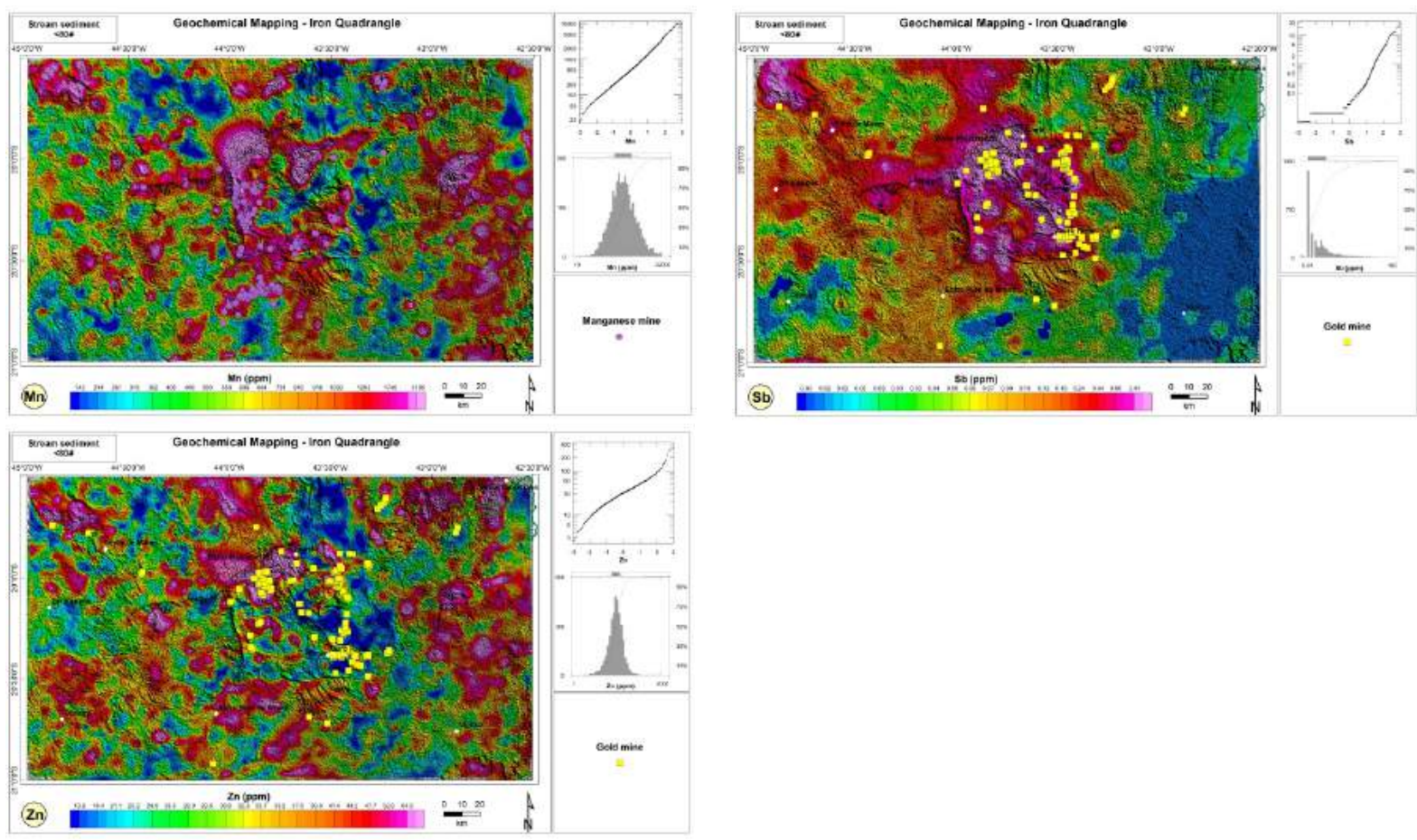

Figure 6 (cont.) Selected pathfinder elements and known gold deposits and mines.
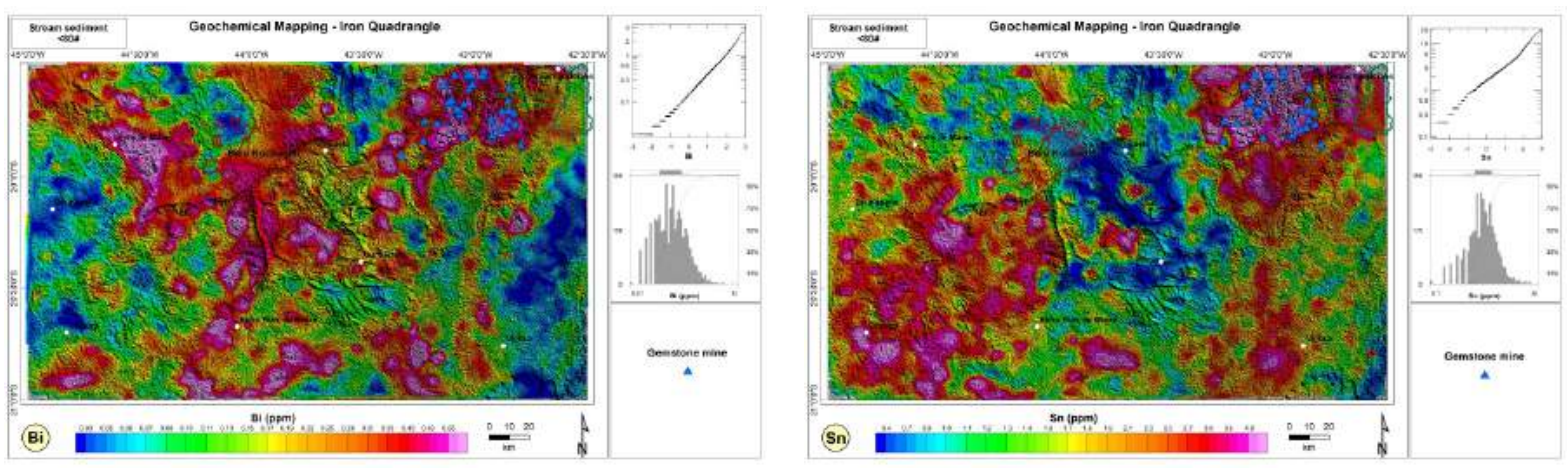

Figure 7

Gemstone deposits and mines and the Bi and Sn distribution.

Table 2 - Factors, Eigenvalues and cumulative percentage for PCA correlation matrix.

\begin{tabular}{ccc}
\hline \multicolumn{3}{c}{ Eigenvalues of correlation matix } \\
\hline Factor & Eigenvalue & cum. \% \\
\hline 1 & 9.068 & 32.4 \\
2 & 5.258 & 51.2 \\
3 & 2.253 & 59.2 \\
4 & 1.873 & 65.9 \\
5 & 1.246 & 70.4 \\
6 & 0.994 & 73.9 \\
7 & 0.928 & 77.2 \\
8 & 0.872 & 80.3 \\
9 & 0.65 & 82.6 \\
10 & 0.544 & 84.6 \\
\hline
\end{tabular}




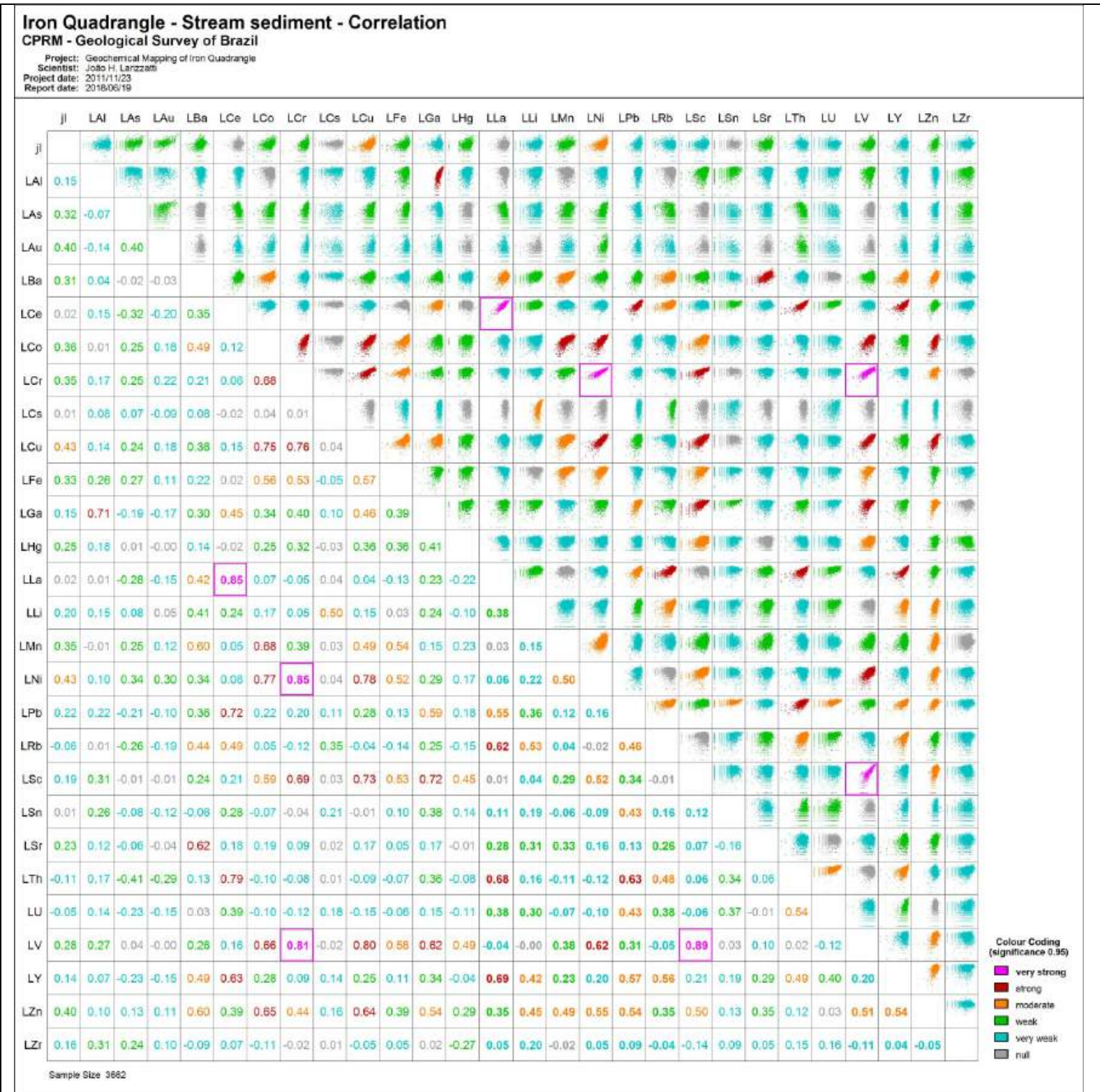

Figure 8

Correlation plot for log-transformed selected elements.

\section{Factor 1}

Factor 1 (Figure 9), which correspond to $32.4 \%$ of total variance, presents significant positive loadings for [ $\mathrm{V}-\mathrm{Cr}-\mathrm{Cu}-\mathrm{Sc}-\mathrm{Co}-\mathrm{Ni}$ ] and less significant negative loadings for [Cs-U$\mathrm{Rb}$ ]. The element association probably reflects the influence of "mafic" or less evolved rock types. High values of this factor indicate ultramafic and/or mafic rocks (Rio das Velhas greenstone belt), while negative values indicate granitic areas. Factor 1 (Figure 10) is enriched over the northeast area of Iron Quadrangle near the junction of Curral and Gandarela ranges, where Rio das Velhas Supergroup greenstone belt rocks outcrop (Archean age); and just south of Ouro Branco range, southernmost part of IQ, where Santo Antonio do Pirapetinga Complex rocks outcrop
(Archean TTG). Factor 1 is also enriched in a north-south trend, east of the study area, where Mantiqueira Complex rocks (Paleoproterozoic TTG) and alluvial sediments (Cenozoic) outcrop.

Negative loadings of Factor 1 appear in the north of the study area, where TTG Mesoarchean rocks of Belo Horizonte Complex outcrop. One can also observe negative values in the western portion of the area, where Itapecerica gneiss, Claudio gneiss and Bonfim granite outcrop. In the center of IQ one can also observe Factor 1 negative values over Bação and Santa Barbara Complexes. In the south of the area negative Factor 1 values appear over Barbacena Complex rocks. All these units are considered of Archean age. 

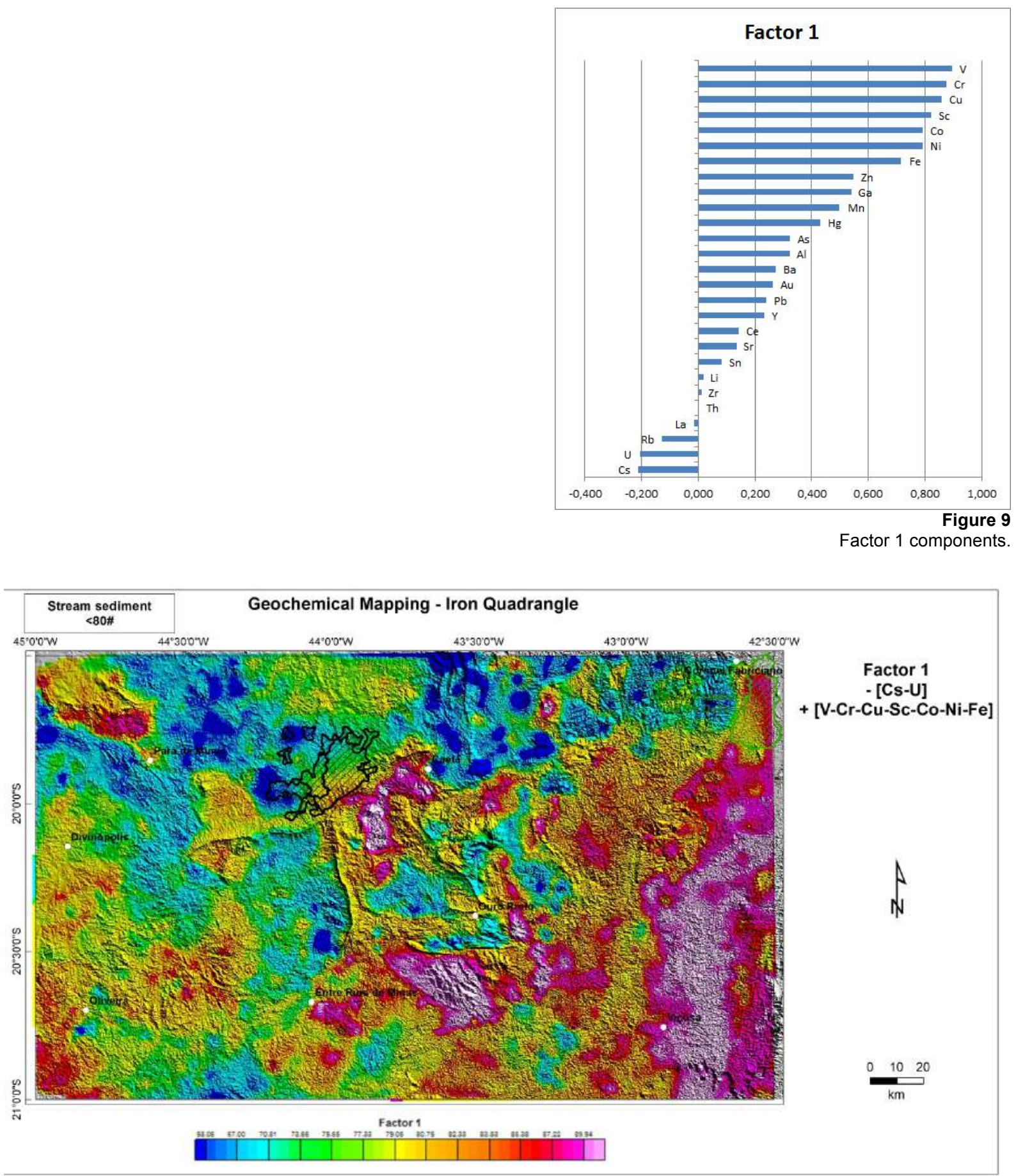

Figure 10

Distribution of Factor 1 values.

\section{Factor 2}

Factor 2 explains $18.8 \%$ of total variance, (Table 2) has low positive loadings for [As$\mathrm{Hg}-\mathrm{Au}]$, which can indicate the presence of hydrothermal alteration and gold mineralization (and pollution). It also has significant negative loadings for [Ce-Th-La-Pb-Rb-Y-U] (Figure 11) over Archean (and some Proterozoic) granitoids/gneisses, especially over Divinópolis and Bonfim complexes. As can be observed in Figure 12, positive loadings of Factor 2 are reasonably well matched with known gold deposits. But Factor 2 patterns should be interpreted with caution, as many of $\mathrm{As}, \mathrm{Hg}$ and $\mathrm{Au}$ values are below or close to detection limits. 


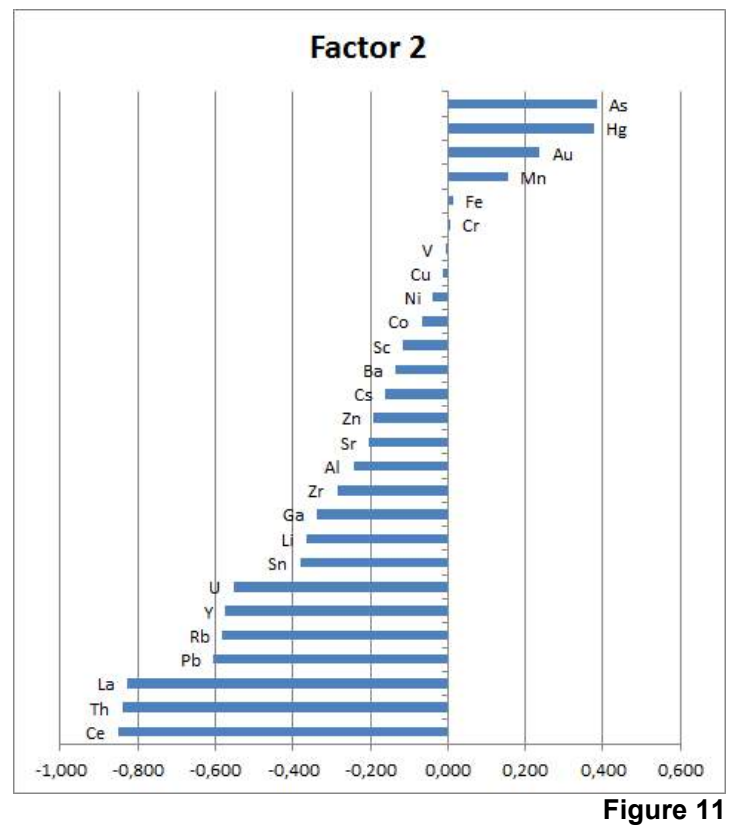

Factor 2 components.

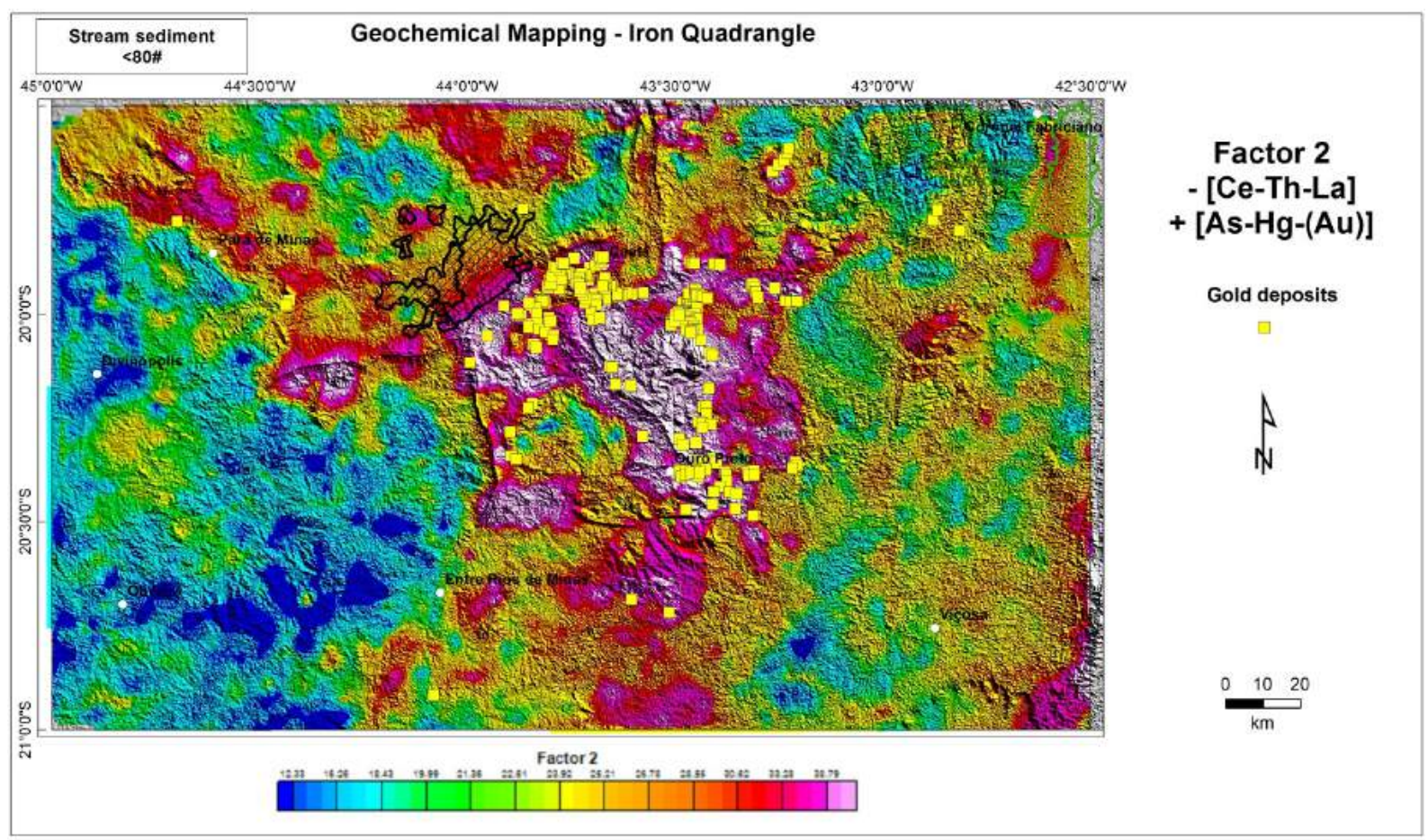

Figure 12

Distribution of Factor 2 values.

\section{Factor 3}

Factor $3(8.0 \%$ of total variance, Table 2 ; Figure 13) displays significant negative loadings for [Ba-Sr-Li], possibly indicating the presence of carbonate rocks. High negative Factor 3 values (Figure 14) are arranged over the Bambui Group (Neoproterozoic age) and the Minas Supergroup (Paleoproterozoic age) rocks. The northwest sector of IQ also shows a NW-SE trend with negative values for Factor 3 where a deformation zone is observed. South of IQ also shows a restricted area where high negative values of Factor 3 occur. 

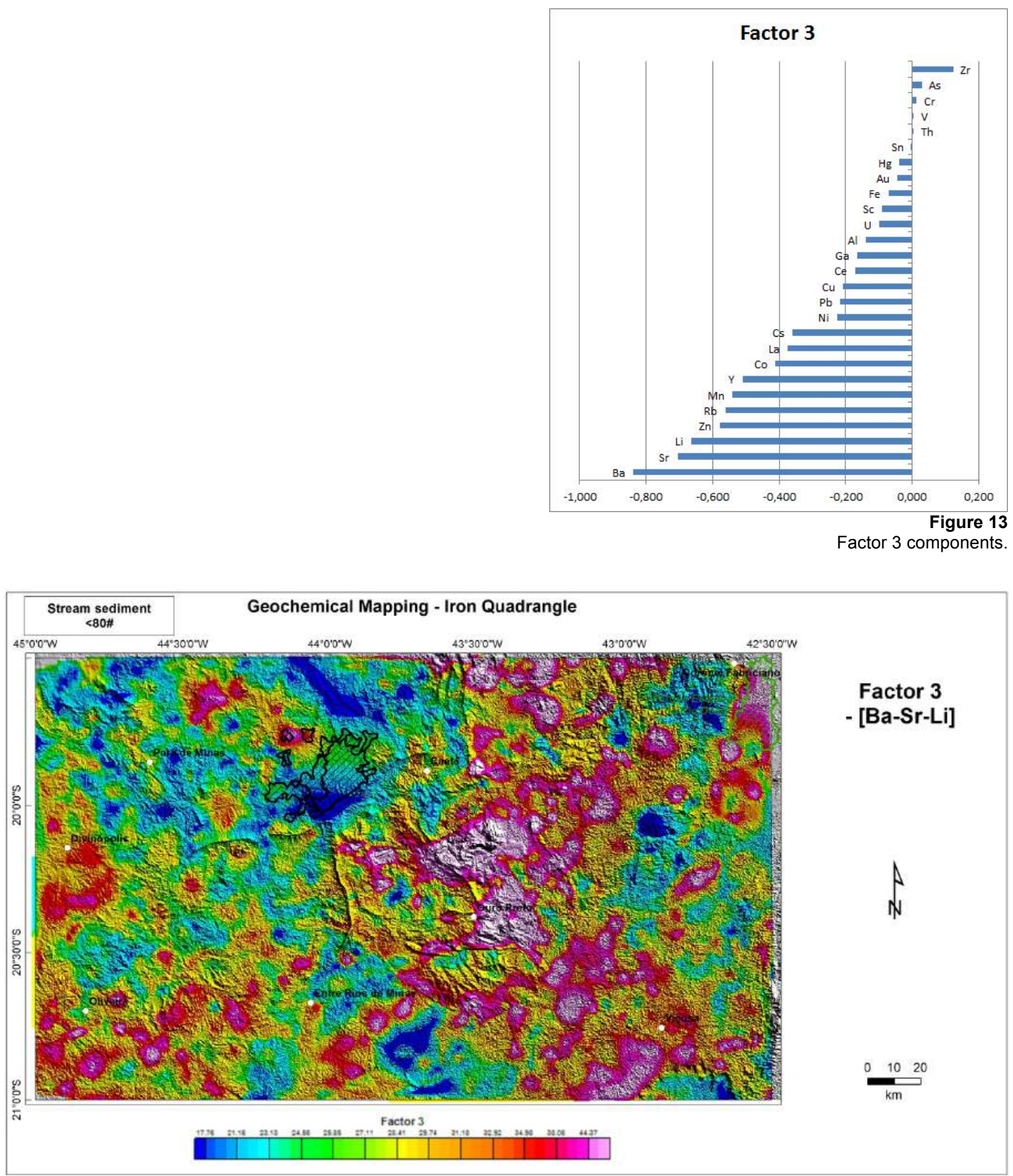

Figure 14

Distribution of Factor 3.

\section{Factor 4}

Factor 4 (6.7\% of total variance, Table 2; Figure 15) shows significant positive loadings for [Zr-Au-As], which may indicate gold mineralization, but the correlation of $\mathrm{Zr}$ with As and $\mathrm{Au}$, respectively, is weak and very weak, and should be interpreted with caution. Figure 16 indicates that Factor 4 does not show very good correlation with known gold deposits as happens with Factor 2. There is an

enriched corridor for Factor 4 coinciding with the Curral ridge; and a much smaller enrichment corridor southwest of IQ. The northwest portion of the study area also shows enrichment in Factor 4 values. On the other hand, the Araçuaí orogenic belt, east of IQ and of the São Francisco Craton shows negative values for Factor 4. 


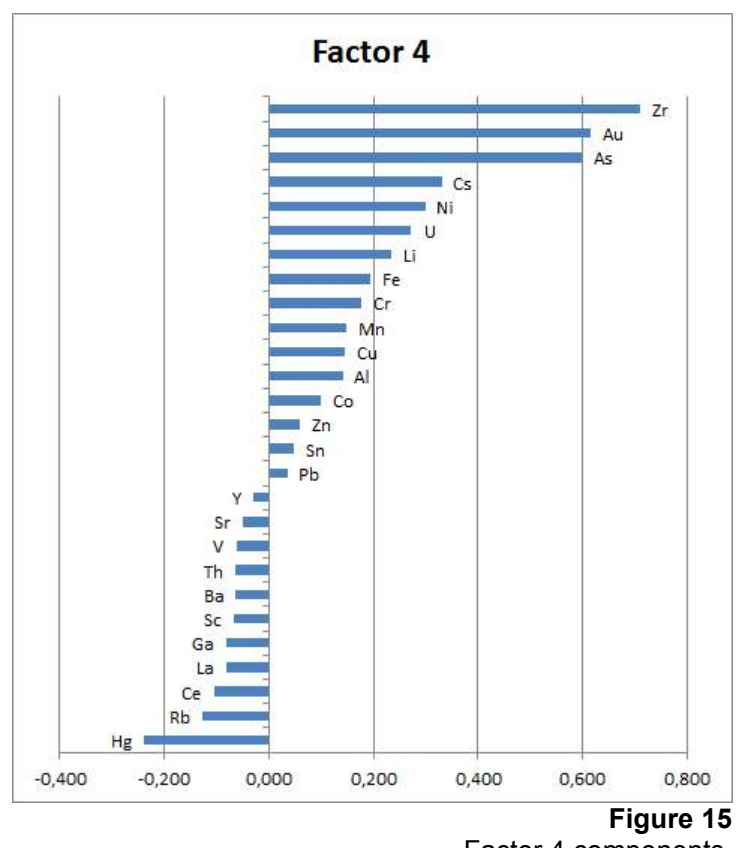

Factor 4 components.

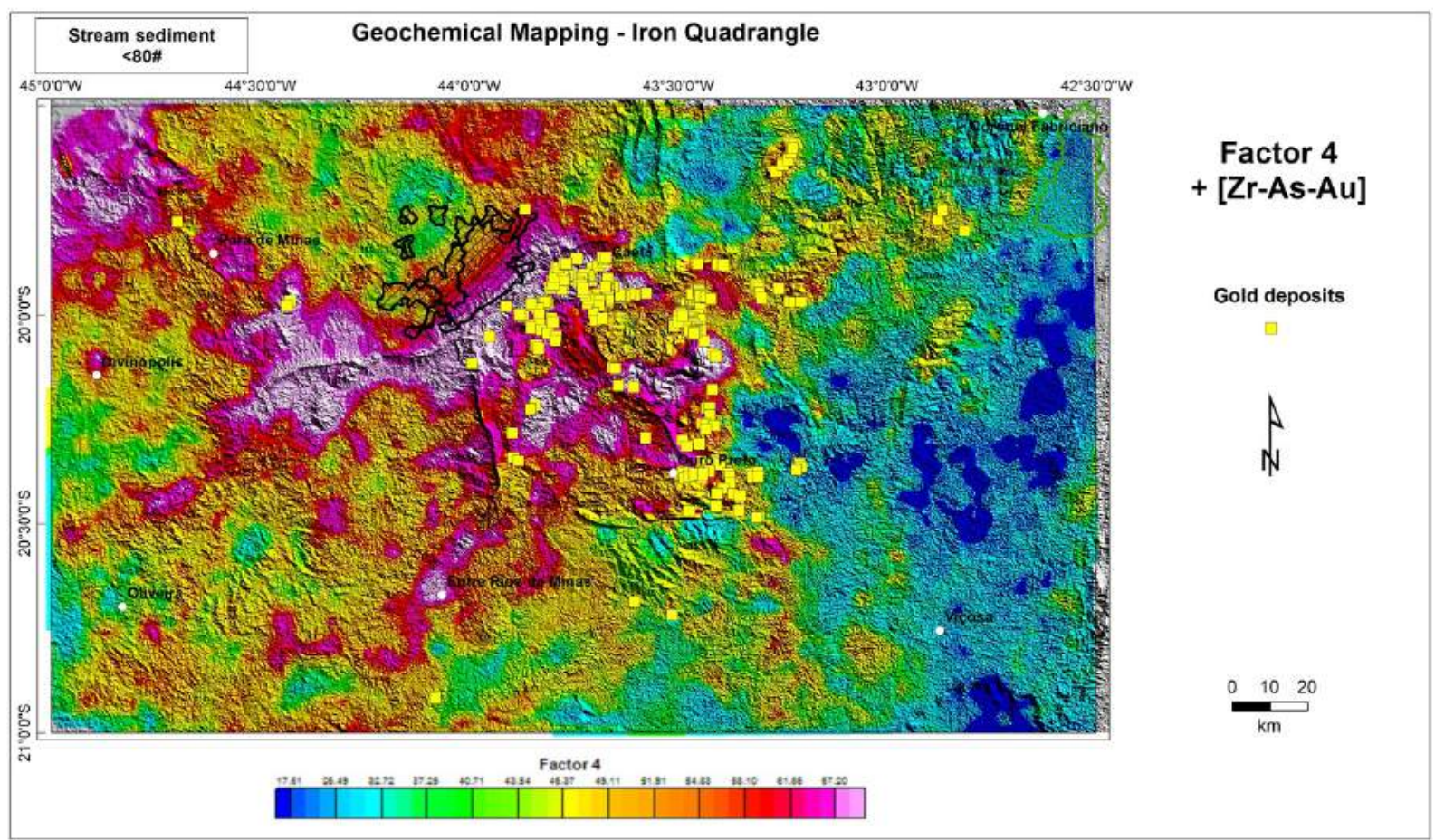

Figure 16

Distribution of Factor 4 values.

\section{Factor 5}

Factor $5(4.5 \%$ of total variance, Table 2 , Figure 17) presents significant positive loadings for [Sn-Al-Ga-Hg-Pb-Cs-U-Sc] and can indicate evolved granite facies and/or

pegmatites. Higher values of Factor 5 can be found just about an area northeast of IQ, where known precious stone mineralization occur (Figure 18). 


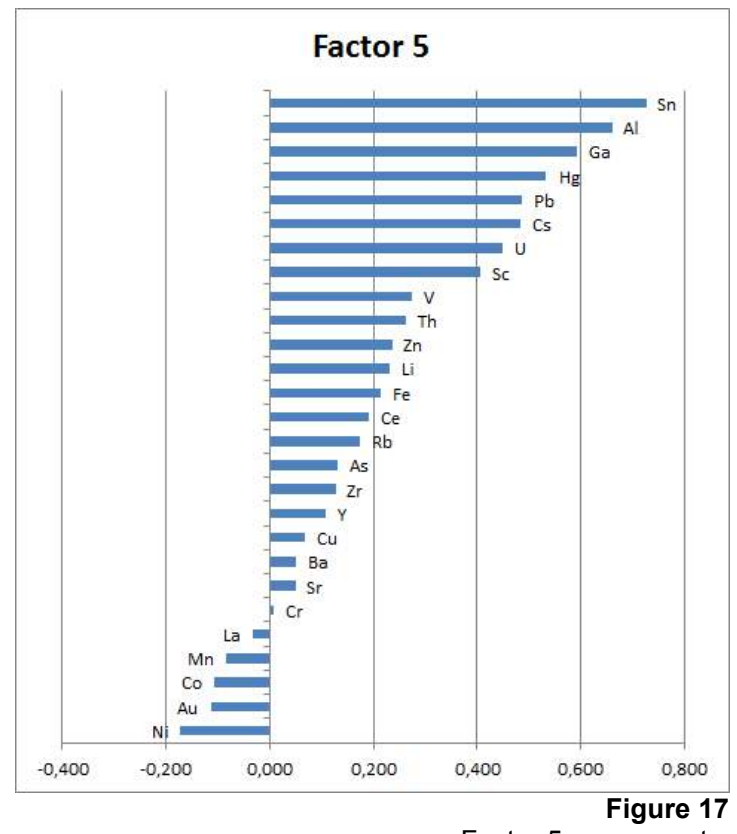

Factor 5 components.

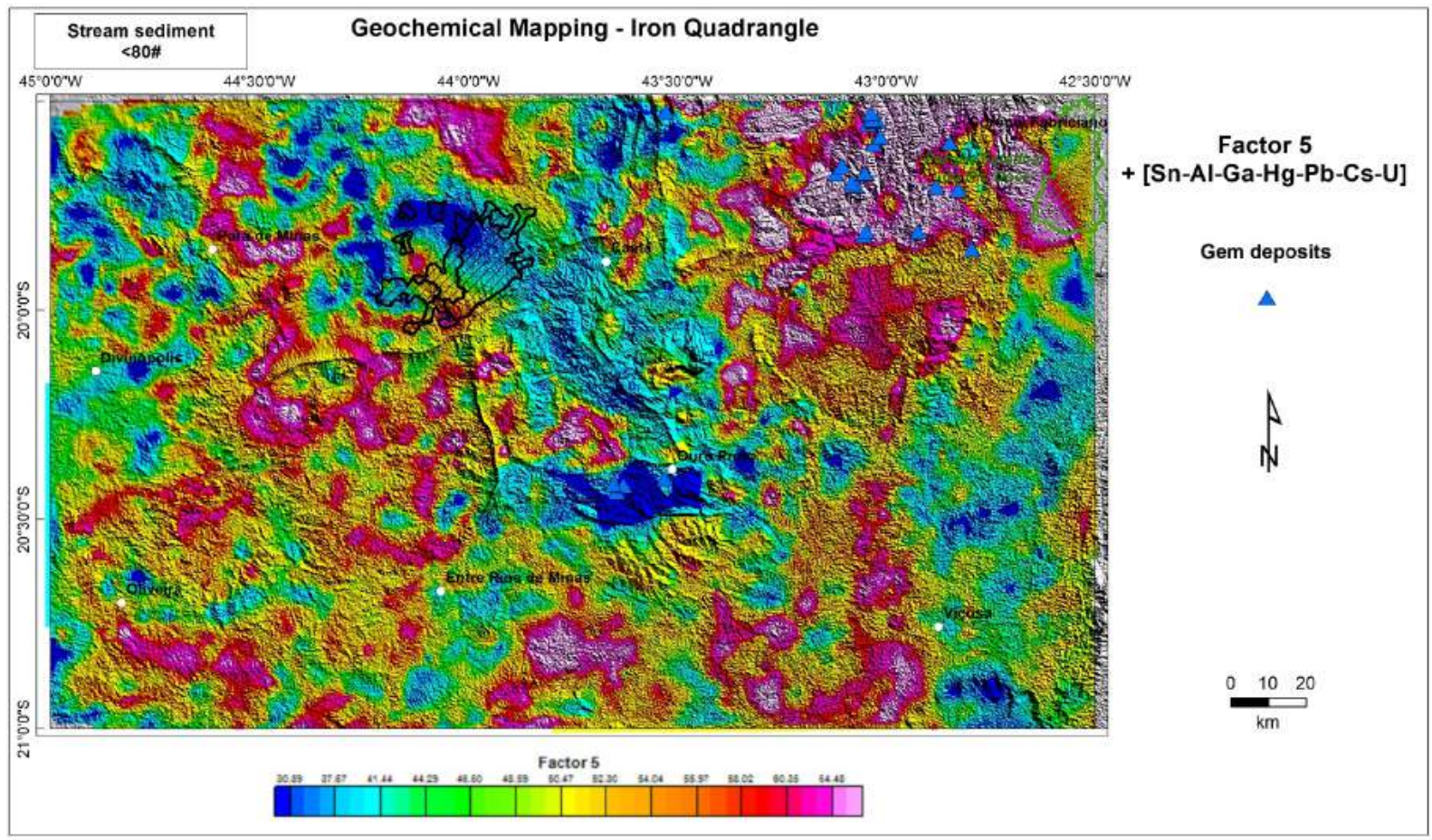

Figure 18

Distribution of Factor 5 values.

\section{DISCUSSION}

One of the reasons for the achievement of geochemical mapping in IQ region is the presence of important mineral occurrences. Despite of the importance of its mineral deposits, IQMP geochemical features in surface materials are not well established at regional scale, even after decades of studies.

The geochemical maps displayed in this article show the effectiveness of these data to point out geological features and processes: areas where specific rock units, hydrothermal alteration, $\mathrm{Fe}, \mathrm{Au}, \mathrm{Mn}$ and gemstone mineralization occur are quite clearly displayed in the geochemical maps. The ability of geochemical mapping to identify mineralized areas depends on the extent and continuity of outcrops, on the geochemical contrast between mineralized and barren areas or rock units, and on sampling density, which allow the collected samples effectively represent the geological features and processes. Nevertheless, care must be taken in 
the data interpretation. Due to the regional scale, these data do not point to specific geochemical anomalies related to isolated mineral deposits. Moreover, stream sediment samples generally do not have a straightforward link to the rock basement, considering several factors that influence their composition, like supergene and anthropogenic processes. Some elements are admittedly linked to a specific rock type. However, the weathering process could modify partially or entirely the geochemical associations present in the fresh rocks. In other words, the more intense the weathering acting on the rock, the lower the evidence of its original geochemical association. Consequently, it generates weak correlations among the chemical elements, presenting diffuse geochemical dispersion patterns. The correlation coefficients calculated for stream sediments data are shown in Figure 8, being highlighted and the most significant correlations.

\subsection{IRON DEPOSITS}

The $\mathrm{Fe}$ deposits are concentrated in the Minas Supergroup (Itabira Group), where the Cauê Formation presents the banded iron formation (BIF) of Superior Lake type and the Gandarela Formation displays dolomites, with a transitional limit between them. Metamorphic and weathering processes provided the enrichment of iron that exceeds $60 \%$ wt. Fe (Spier 2005, Rosiere et al. 2008). The Figure 6 shows the $\mathrm{Fe}$ distribution in stream sediments and the main $\mathrm{Fe}$ deposits in

\subsection{MANGANESE DEPOSITS}

The Mn deposits are related to $\mathrm{Fe}$ deposits and have an average content of $25 \mathrm{wt} . \% \mathrm{Mn}$, reaching a maximum of $40 \%$ w.t. Mn. These high concentrations are reached by the weathering of Mn-marbles and Mn-itabirites of the Minas Supergroup, mainly in the Itabira, Piracicaba and Caraça Groups (Dorr et al.
Bölviken et al. (1990) proposed that metallogenic provinces coincide with geochemical provinces. For these authors, geochemical province is defined as an abnormal spatial distribution and concentration of an element (or a set of elements), in a certain kind of sample, measured by a certain analytical technique. In some cases, the location of anomalous areas in soil or stream sediment coincides with the mineral deposit location. It should be noted that 1) anomalous areas present variable size; 2) some elements form similar anomalous areas when compared to other elements; 3 ) some mineral deposits do not coincide with anomalies of those elements directly linked to the mineralization (e.g., Au). In the following topics the relationship among IQMP mineral deposits and the stream sediment geochemistry in the study area will be discussed.

IQ region. The Fe mines located in the western portion of IQ overlap the NNW-SSE anomalous trend which extends parallel to the Moeda mountain range. In the southeastern portion, next to Ouro Preto municipality, another anomalous trend overlaps known $\mathrm{Fe}$ deposits, and the same pattern is presented in the Curral mountain range (south to the Belo Horizonte Metropolitan Region) and the surroundings of Barão de Cocais and Socorro municipalities.

1956). The Figure 6 shows the Mn distribution in stream sediments and the main Mn deposits in IQ. A high overlap between anomalous bands and the main Mn deposits is observed mainly in the Moeda mountain range and in metasediments from Mineiro Belt, where the largely known Mn deposits are located.

\subsection{GOLD DEPOSITS AND THEIR RELATIONSHIP TO TRACE ELEMENTS DISTRIBUTION}

The Rio das Velhas Greenstone Belt (Archean age) hosts important orogenic gold deposits in IQ. There are three types of gold deposits: 1) structure-controlled, with sulfide substitutions zones in BIFs; 2) disseminated sulfide and gold associated to shear zones in hydrothermalized rocks; 3) quartz-carbonatesulfide veins in mafic, ultramafic, felsic and also in metasedimentary clastic rocks (Lobato et al. 2001). For the gold deposits hosted in itabirites, Rose et al. (1979) point out Au, As, $\mathrm{S}$ and $\mathrm{Sb}$ as pathfinders. Boyle (1979) presents the decrescent order of elements related to gold deposits: $\mathrm{S}, \mathrm{Se}, \mathrm{Te}, \mathrm{As}, \mathrm{Sb}, \mathrm{Bi}, \mathrm{Cu}, \mathrm{Ag}, \mathrm{Zn}, \mathrm{Cd}$, $\mathrm{Hg}, \mathrm{Sn}, \mathrm{Pb}, \mathrm{Mo}, \mathrm{W}, \mathrm{Fe}, \mathrm{Pt}, \mathrm{Pd}, \mathrm{Co}$ and $\mathrm{Ni}$. 
The primary gold deposits of IQ present great variety of sulfide minerals and can be enriched in one or more of the following elements: $\mathrm{Au}, \mathrm{Ag}, \mathrm{As}, \mathrm{Cu}, \mathrm{Pb}, \mathrm{Pd}, \mathrm{Sb}, \mathrm{Se}, \mathrm{Zn}$ (Lobato et al. 2001, Olivo et al. 2001, Vial et al. 2007a,b,c, Ribeiro-Rodrigues et al. 2007, Pereira et al. 2007, Junqueira et al. 2007, Cabral \& Lehmann 2007). The record of gold deposits in the GEOSBG database, sometimes, do not displays direct correlation to $\mathrm{Au}$ anomalous areas presented in this study. The reasons for this fact could be related to: 1) the sample density adopted; 2) the geological matrix sampled; 3) lower sensibility of the analytical method for $\mathrm{Au}$; 4) the techniques for the elaboration of the geochemical maps; and $5)$ the complexity of the geochemical associations of the Au mineral deposits.

The geochemical distribution of As in stream sediments displays an enrichment in almost all known gold deposits and there is a markedly relationship between $\mathrm{As}$ and $\mathrm{Au}$ in supergene and hypogene processes (Boyle 1979), making As the main pathfinder of gold deposits. Figure 6 shows the As distribution in stream sediments and the main gold deposits in IQ. Many authors observed the presence of arsenopyrite in IQ gold deposits and the geochemical data show strong correlation between As and many gold deposits confirming the usefulness of As as gold pathfinder.

Still according to Boyle (1979), $\mathrm{Sb}$ is enriched in most of the hypogene gold deposits and in vein-type gold deposits, however, in the lode-type deposits, $\mathrm{Sb}$ presents its highest concentrations. The distribution and behavior of $\mathrm{Sb}$ in IQ area is similar to As and coincides with many gold deposits, which confirms this element as an efficient Au pathfinder. Figure 6 shows the $\mathrm{Sb}$ distribution in stream sediments and the main gold deposits in IQ. It is notorious that high $\mathrm{Sb}$ concentrations highlight strongly the IQ itself, suggesting that the structures that characterize the Iron Quadrangle are important conducts to mineralizing fluids.

Copper is an element constantly related to all kinds of gold deposits, nevertheless, in the most vein-type gold deposits (gold-quartz deposits), $\mathrm{Cu}$ concentration is generally low (Boyle 1979). Copper distribution in the study area (Figure 5) shows more restricted anomalous and segmented areas when compared to other trace elements. It is observed that there are two situations involving $\mathrm{Au}$ and $\mathrm{Cu}:$ 1) $\mathrm{Cu}$ anomalous areas overlapping gold deposits; 2) low $\mathrm{Cu}$ concentration areas overlapping gold deposits. This fact suggests that mineralizing fluids with different compositions acted in the study region.

Silver is also an element constantly related to primary gold deposits, but its concentration is largely variable. In the supergene environment, the behavior of $\mathrm{Ag}$ and $\mathrm{Au}$ is very different; $\mathrm{Au}$ tends to be relatively immobile next to the primary source, while Ag tends to be solubilized in surface water and groundwater (Boyle 1979, Bowell 1992, Gray et al. 1992, Thornber 1992). Silver, as a gold deposit pathfinder, is not always efficient. Figure 6 shows that some gold deposits of the study area, especially those outside IQ, are coincident to low $\mathrm{Ag}$ concentrations area. If one looks at IQ strictu sensu and to Ag concentration, it will be noted that there is a good correlation between high $\mathrm{Ag}$ values and some Au mines. This will also indicate, as with copper, that gold deposits present at IQ are probably linked to more than one genetic process.

Zinc, as the most trace elements above mentioned, is present in many gold deposits but shows great variability on its concentration. In the supergene environment, $\mathrm{Zn}$ tends to have different behavior from $\mathrm{Au}$, becoming more mobile, mainly under influence of meteoric water (hydromorphic dispersion; Boyle 1979, Rose et al. 1979). In Figure 6, it is noted that some gold deposits are overlapped by $\mathrm{Zn}$ anomalous areas (northern portion of the IQ), while several deposits located at western portion coincide with areas of low $\mathrm{Zn}$ concentration. This fact could be linked to the $\mathrm{Zn}$ behavior in supergene environment or different geochemical signatures of different primary Au deposits.

The chalcophile trace elements behavior described in this study show some kind of relationship to gold deposits. These elements are associated with sulfides and hydrothermal alteration in many gold deposits around the world. "Sulfur is an ubiquitous component of hydrothermal ore solutions..." (Seward 1993) and chalcophile elements are, many times, linked to mineral deposits. Not only the transport, but also the mechanisms of $\mathrm{Au}$ precipitation are important when one thinks about geochemical signature of gold deposits. The extent and preferential sites of gold deposition will be dependent upon the relationship between the hydrology and permeability of the hydrothermal system and 
the gold complexes equilibria. Therefore, any process that destabilize Au-ligant relationship in a hydrothermal solution will lead to gold precipitation. Then, the presence of lithological changes, and/or structural discontinuities and/or sulfide mineral precipitation can precipitate gold. The same occurs when deep fluids mix with oxygenated meteoric waters in the upper parts of hydrothermal systems. It is important to note that different metal sulfides precipitate in particular conditions (Seward 1993), this will help in explaining different compositions of primary deposits present at IQ.

Archean lode gold deposits are commonly termed 'gold-only' deposits because of the extreme enrichment of $\mathrm{Au}$ relative to other metallic elements (Groves \& Foster 1993).

\subsection{GEMSTONES}

The Coronel Fabriciano region, located in the northeast portion of the study area, belongs to the Itabira-Ferros Pegmatite Field, which composes the Oriental Pegmatitic Province (Netto \& Araújo 1997, Correia-Neves et al. 1986). This area is characterized by a volcanosedimentary sequence and a Paleoproterozoic granitic event, correlated to the Borrachudos Suite. According to these authors, in this region, several pegmatitic bodies outcrop and the mineralized ones are located next to the borders of granitoid rocks nearby the contact with ultramafic schists and gneisses. In this region gemstone mines and 30 artisanal mining ('garimpo') spots are found nine, being the

\section{CONCLUSIONS AND RECOMMENDATIONS}

The geochemical mapping of IQ and its surroundings demonstrated that regional geochemical survey is a powerful tool to mineral exploration, geological mapping, environmental studies and sustainable development. Despite the intensive mining, agricultural and industrial activities in the study region, the results obtained in this work presented strong relationship to geology. This feature should be considered by regulatory authorities for the definition of "contaminated areas". This work offers an important database, which defined a geochemical behavior and distribution of chemical elements and provided analytical results of stream sediments for future studies.
According to these authors, these deposits show a characteristic association of $\mathrm{Au}$ with As, W, Ag, Sb, Te and B, with a generally low base-metal and Mo content. Focusing the geochemical map for Factor 2 (As-Hg-(Au)), presented in Figure 12, one can note that these elements are coincident to almost all gold occurrences in IQ. Antimony also shows good correlation with gold deposits (Figure 6). Unfortunately, due to the presence of many results below the lower detection limit for these elements, they were not used in Principal Component Analysis. Nevertheless, the results of the multivariate studies presented here show that this tool presents great potential in geochemical exploration and geological mapping.

main gemstones are aquamarine, alexandrite, amethyst and topaz.

According to Pinto et al. (1997), the mineralized pegmatites are complex and zoned. The mineralization occurs as irregular geodes, related to black tourmaline (schorlite) which, sometimes, occurs in metric crystals. The best gemstones occur inside the geodes. The Borrachudos Suite has granitoid rocks with alkaline composition and displays anomalous concentrations of $\mathrm{Bi}$ and $\mathrm{Sn}$ (Figure 7). The anomalous area for these elements overlaps the mining areas. The multielementary map extracted from Factor 5 (Figure 18) also corroborates this outstanding geochemical feature.

The costs and risks involved in mineral exploration can be reduced if high quality geological data is provided to the mineral sector. The mineral industry may focus its investments in high mineral potential areas, lowering costs, increasing the discovery of new deposits and generating employment, income and sustainable development.

The demand for mineral inputs, energy, water and other kind of materials by the Brazilian population is increasing every day. The efficient management of land use and occupation by government authorities depends on the knowledge of structure, composition and dynamics of crustal earth and its effects upon people and ecosystems. Thus, it is neces- 
sary that the geological information be available for the decision makers. For this purpose, we recommend that this kind of

\section{ACKNOWLEDGMENTS}

We thank CPRM - Geological Survey of Brazil for giving us permission to publish this work. We thank our colleagues, geologists Clayton P. Pinto; Orivaldo F. Baltazar, Valter S. Vieira and Márcio A. Silva for geological input and discussions at various stages of this

\section{REFERENCES}

Almeida, F.F.M. 1978. A evolução dos crátons Amazônico e do São Francisco comparada com a de seus homólogos do hemisfério norte. In: SBG, Congr. Bras. Geol., 30, Recife, Anais, V6, p. 2393-2407.

Amor,S. (2011) Geochemical Applications of Commonly-Analyzed Elements. Available at: $<$ http://www.dirtbagger.goinfo.com/applabs/ele ments.html>. Access: July 2018.

Barbosa G. V. \& Rodrigues D. M. S. 1967. Quadrilátero Ferrífero. Belo Horizonte: UFMG, IGC, 130pp.

Baltazar, O.F. \& Zucchetti, M. (2007) Lithofacies associations and structural evolution of the Archean Rio das Velhas greenstone belt, Quadrilátero Ferrífero, Brazil: A review of the setting of gold deposits. Ore Geol. Rev., 32: 471-499.

Bierlein, F.P., Groves, D.I., Goldfarb, R.J., Dubé, B. 2006. Lithospheric controls on the formation of provinces hosting giant orogenic gold deposits. Mineralium Deposita, 40: 874-886.

Bölviken B., Kullerud G., Loucks R.R. 1990. Geochemical and metallogenic provinces: a discussion initiated by results from geochemical mapping across northern Fennoscandia. J. Geochem. Explo., 39: 49-90.

Bowell R.J. 1992. Supergene gold mineralogy at Ashanti, Ghana: implications for the supergene behavior of gold. Min. Mag., 56: 545-560.

Boyle R.W. 1979. The geochemistry of gold and its deposits. (Geological Survey Bulletin, 280). Ottawa: Geological Survey of Canada. 564pp.

Butt C.R.M., Zeegers H. 1992. Climate, geomorphological environment and geochemical dispersion models. In: Kalevi Kauranne, Reijo Salminen and Karin Eriksson (Ed.). Regolith exploration in tropical and subtropical terrains. (Handbook of exploration geochemistry, v. 4) Amsterdam: Elsevier, p. 324.

Cabral A.R.; Lehmann B. 2007. Seleniferous minerals of palladium and platinum from ouro preto-bearing mineralisation in Brazil. Ore Geol. Rev., 32: 681-688. project should be replicated in several parts of the country.

work. We thank Otavio A.B. Licht for the invitation to submit our work to this special issue and for technical discussions. We thank an anonymous reviewer who improved our text.

Carranza E.J.M., 2009. Geochemical Anomaly and Mineral Prospectivity Mapping in GIS. Handbook of Exploration and Environmental Geochemistry. Elsevier, Amsterdam. 350pp.

Coelho, V.V. (2015) Modelagem metamórfica e geocronologia de xistos e anfibolitos do Grupo Nova Lima, Supergrupo Rio das Velhas, Quadrilátero Ferrífero. Dissertação de Mestrado. Universidade Federal de Ouro Preto, $183 p$.

Correia Neves J.M., Pedrosa-Soares A.C., Marciano V.R. 1986. A Província Pegmatitica Oriental do Brasil à luz dos conhecimentos atuais. Rev. Bras. Geoc., 16: 106-118.

Davis J. C. 1973. Statistics and Data Analysis in Geology. New York: John Willey \& Sons, 550 p.

De Paula R. Z. A. 2002. Indústria em Minas Gerais: origem e desenvolvimento. In: Seminário sobre a economia mineira, 10, Diamantina. Anais...Available at: $<$ http://www.cedeplar.ufmg.br/diamantina2002/ textos/D13.PDF>. Access: July, 2013.

Dorr, J.V.N.; Coelho, I.S.; Horen, A. 1956. The manganese deposits of Minas Gerais, Brazil. In: INTERNATIONAL GEOLOGICAL CONGRESS, 20, Mexico D.F. [Anais]... [S.1.: S.n., 1956]. 3: 279-346.

Gray D.J., Butt C.R.M., Lawrance L.M. 1992. The geochemistry of gold in lateritic terrains. In: : Kalevi Kauranne, Reijo Salminen and Karin Eriksson (Ed.). Regolith exploration in tropical and subtropical terrains. (Handbook of exploration geochemistry, v. 5), Amsterdam: Elsevier. 3-24.

Grunsky, E.C. 2017. The interpretation of regional geochemical survey data. In: DECENNIAL INTERNATIONAL CONFERENCE ON MINERAL EXPLORATION, 5.,Sep. 7-12, 2007, Toronto. Proceedings of Exploration 17. Toronto: Decennial Mineral Exploration Conferences, p. 139-182.

Grunsky E.C., 2010. The interpretation of geochemical survey data. Geochemistry, Exploration, Environment and Analysis. 10: 2774. 
Darnley A.G., Bjiirklund A., Belviken B., Gustavsson N., Koval P.V., Plant J.A., Steenfelt A., Tauchid M., Xuejing X., Garrett R.G., Hall G.E.M. (Eds.) 1995. A global geochemical database for environmental and resource management. (Earth Sciences 19), Paris: UNESCO, $122 \mathrm{pp}$.

Heilbron, M.; Pedrosa-Soares, A.C.; Campos Neto, M.C.; Silva, L.C.; Trouw, R.A.J.; Janasi, V.A. 2004. Província Mantiqueira. In: Geologia do continente Sul-Americano: evolução da obra de Fernando Flávio Marques de Almeida. Beca Editora. p. 203-235.

IBGE. 2006. Mapa de clima do Brasil. Rio de Janeiro. 1 mapa. Escala1: 5.000.000.

IBGE. 2010. Mapa da cobertura e uso da Terra. Rio de Janeiro, 2010. 1 mapa. Escala 1: 5.000.000.

Junqueira P.A., Lobato L.M., Ladeira E.A., Simões E.J.M. 2007. Structural control and hydrothermal alteration at the BIF-hosted Raposos lode-gold deposit, Quadrilátero Ferrífero, Brazil. Ore Geol. Rev, 32: 571-595.

Lapworth D.J., Knights K.V., Key R.M., Johnson C.C., Ayoade E., Adekanmi M.A., Arisekola T.M., Okunlola O.A., Backman B., Eklund M., Everett P.A., Lister R.T., Ridgway J., Watts M.J., Kemp S.J., Pitfield P.E.J. 2012. Geochemical mapping using stream sediments in west-central Nigeria: Implications for environmental studies and mineral exploration in West Africa. Appl. Geochem. 27: 1035-1052.

Levinson A.A. 1974. Introduction to exploration geochemistry. Maywood: Applied Publ. 605pp.

Licht O.A.B. 1998. Prospecção Geoquímica: Princípios, Técnicas e Métodos. Rio de Janeiro: CPRM. 216pp.

Lobato L.M., Rodrigues L. R., Vieira F. 2001. Brazil's premier gold province: part II: geology and Genesis of gold deposits in the Archean Rio das Velhas greenstone belt, Quadrilátero Ferrífero. Mineralium Deposita, 36:249-277.

Manly, B.F.J. 1986. Multivariate Statistical Methods: A Primer. London: Chapman Hall. 110pp.

Netto C., Araújo M. C. 1997. Projeto Leste, Minas Gerais: Cadastramento Mineral: blocos 1 e 2 . Belo Horizonte, COMIG/CPRM. 74p.

Noce, C.M., Machado, N., Teixeira, W., 1998. U$\mathrm{Pb}$ geochronology of gneisses and granitoids in the Quadrilatero Ferrifero (Southern São Francisco craton): age constraints for Archean and Paleoproterozoic magmatism and metamorphism. Rev. Bras. Geoc., 28: 95-102.

Olivo G.R., Gauthier M., Williams-Jones A.E., Levesque M. 2001. The Au-Pd mineralization at the Conceição iron mine, Itabira District, southern São Francisco craton, Brazil: an example of jacutinga-type deposit. Econ. Geol., 96: 61-74.

Pedrosa-Soares, A.C \& Wiedmann-Leonardos. 2000. Evolution of the Araçuaí Belt and its connection to the Ribeira Belt, eastern Brazil. In: U.G. Cordani, E.J. Milani, A. Thomaz Filho,
D.A. Campos (eds.). Tectonic Evolution of South America. 31st Int. Geol. Congr., Rio de Janeiro, p. 265-285.

Pereira S.L.M., Lobato L.M., Ferreira J.E., Jardim E.C. 2007. Nature and origin of the BIF-hosted São Bento gold deposit, Quadrilátero Ferrífero, Brazil, with special emphasis on structural controls. Ore Geol. Rev, 32: 571-595.

Pinto, C.P., Drumond, J.B.V., Moreira, A M.D. 1997. Geologia econômica e metalogenia. In: Pinto, C.P., Drumond, J.B.V., Féboli, W.L. (Org.) Projeto Leste: geologia, nota explicativa e mapa geológico integrado. Belo Horizonte: CPRM.

Reimann C., Filzmoser P., Garrett R.G. 2002. Factor analysis applied to regional geochemical data: problems and possibilities. Appl. Geochem. 17: 185-206.

Reimann C., Filzmoser P., Garrett R.G., Dutter R. 2008. Statistical Data Analysis Explained. John Wiley \& Sons Ltd., Chichester, England. 362pp.

Ribeiro-Rodrigues L.C., Oliveira C.G., Friedrich G. 2007. The Archean BIF-hosted Cuiabá Gold deposit, Quadrilátero Ferrífero, Minas Gerais, Brazil. Ore Geol. Rev., 32: 547-570.

Rose A.W., Hawkes H.E., Webb J.S. 1979. Geochemistry in Mineral Exploration. Academic Press, London, 657 pp.

Rosiere C.A., Spier C. A., Rios F.J., Suckau V. E. 2008. The itabirites from the Quadrilátero Ferrífero and related high-grade iron ores: an overview. In: Hagemann, Steffen Gerd et al. (Ed.). Banded Iron Formation-related highgrade iron ore. Rev. Econ. Geo., Chelsea, MI, 15: 223-254.

Seward, T.M. 1993. The hydrothermal geochemistry of gold. In: R.P. Foster (ed.) Gold Metallogeny and Exploration. Chapman \& Hall, London, 209 pp.

Spier C.A. 2005. Geoquímica e gênese das formações ferríferas bandadas e do minério de ferro da mina de Águas Claras, Quadrilátero Ferrífero, MG. Tese de Doutorado - Instituto de Geociências, Universidade de São Paulo, 298 p.

Tabachnick B. G.; Fidell L. S. 2001. Using multivariate statistics. London: Allyn and Bacon. 305 pp.

Teixeira, W., Carneiro, M.A., Noce, C.M., Machado, N. Sato, K., Taylor, P.N.,1996, Pb, Sr and $\mathrm{Nd}$ isotope constraints on the Archean evolution of gneissic-granitoid complexes in the southern São Francisco craton, Brazil. Precambrian Research, 78: 151-164.

Thornber, M.R. 1992. The chemical mobility and transport of elements in the weathering environment. In: Kalevi Kauranne, Reijo Salminen and Karin Eriksson (Ed.). Regolith exploration in tropical and subtropical terrains. (Handbook of exploration geochemistry, v. 4), Amsterdam: Elsevier, 79-96.

Vial D. S., Duarte B.P., Fuzikawa K., Vieira M.B.H. 2007a. An epigenetic origin for the Passagem de Mariana gold deposit, Quadrilátero 
Ferrífero, Minas Gerais, Brazil. Ore Geol. Rev, 32: 596-613.

Vial D.S., DeWitt E., Lobato L.M., Thorman C.H. 2007. The geology of the Morro Velho gold deposit in the Archean Rio das Velhas greenstone belt, Quadrilátero Ferrífero, Brazil. Ore Geol. Rev., 32: 511-542.

Vial D.S., Abreu G.C., Schubert G., RibeiroRodrigues L.C. 2007. Smaller gold deposits in the Archean Rio das Velhas greenstone belt, Quadrilátero Ferrífero, Brazil. Ore Geol. Rev, 32:651-673.

Wedepohl K.H. (Ed.) 1976. Handbook of Geochemistry. Heidelberg: Springer-Verlag. v. 2-1, v. 2-2, v. 2-3, v. 2-4 and v. 2-5. 